$7-\operatorname{Ags} 5^{\prime} \cdot 3: 339$

Bulletin 339

Library.

June, 1932

CHEMICAL INVESTIGATIONS OF THE TOBACCO PLANT

III. TOBACCO SEED

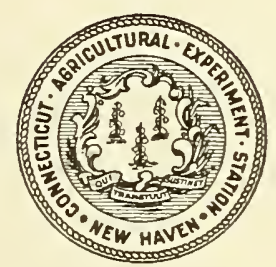

(Tmmertinat

Anrinultural Exparintent Statian

Airu Itaurn 
CONNECTICUT AGRICULTURAL EXPERIMENT STATION BOARD OF CONTROL

His Excellency, Governor Wilbur L. Cross, ex-officio, President

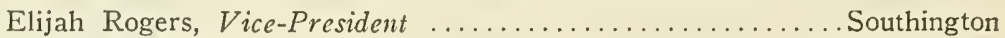

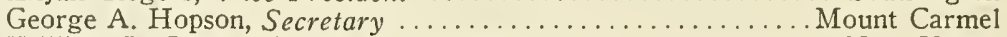
William L. Slate, Director and Treasurer ................. New Haven

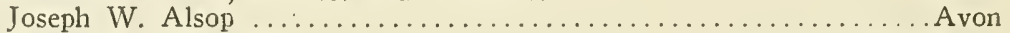

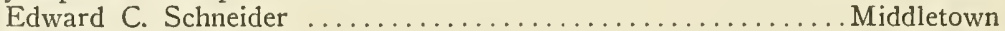

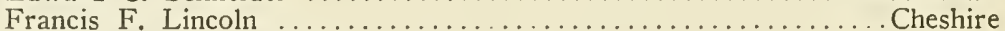
S. McLean Buckingham ................................

\section{STAFF}

Administration.

Analytical Chemistry.

Biochemistry.

Botany.

Entomology.

Forestry.

Plant Breeding.

Soils.

Tobacco Substation at Windsor.
William L. Slate, B.Sc., Director and Treasurer.

Miss L. M. BRautlecht, Bookkecper and Librarian.

Miss Dorothy AmRine, B.LitT., Editor.

G. E. GRAHAM. In Charge of Buildings and Grounds.

E. M. Bailey, Pri.D., Chemist in Charge.

C. E. SHEPARD

OWEN L. NOLAN

HARRY J. FISHER, PH.D. Assistant Chemists.

W. T. Mathis

David C. Walden, B.S

FraNk C. SheLdon, Laboratory Assistant.

V. L. Churchill, Sampling Agent.

Mrs. A. B. Vosburgh, Secretary.

H. B. VICKery, YH.D., Biochemist in Charge.

Lafayette B. Mendel, Ph.D., (Yale University) Research Associate.

George W. Pucher, Ph.D., Assistant Biochemist.

G. P. Clinton, Sc.D., Botanist in Charge.

E. M. Stoddard, B.S., Pomologist.

Miss Florence A. MícCormick, PH.D., Pathologist.

A. A. Dunlap, Pr.D., Assistant Mycologist.

A. D. McDonnell, General Assistant.

MrS. W. W. KeLSEY, Secretary.

W. E. Britton, Ph.D., D.Sc., Entomologist in Charge, State Entomologist

B. H. WALDEN, B.AGR,

M. P. Z Z APPE, B.S

Philip Garman, PH.D.

ROGER B. FRIEND, PH.D.

NEELY TURNER, M.A.

JoHN T. AsH WORTH, Deputy in Charge of Gipsy Moth Control.

R. C. BOTSFORD, Deputy in Charge of Mosquito Elimination.

J. P. Johnson, B.S., Deputy in Charge of Asiatic and Japanese Beetle Ouarantines.

Mrs. Gladys Brooke, B.A., Secretary.

Walter O. Filley, Forester in Charge.

H. W. Hicock, M.F., Assistant Forester.

J. E. Riley, JR., M.F., In Charge of Blister Rust Control.

Miss Pauline A. Merchant, Secretary.

Don ald F. Jones, Sc.D., Geneticist in Charge.

W. Ralph SingLETON, Sc.D., Assistant Geneticist.

LaWrenCe C. Curtis, B.S., Assistant.

Mrs. Catherine R. Miller, M.A., Secretary.

M. F. Morgan, M.S., Agronomist in Charge

H. G. M. JACOBSO N, M.S., Assistant Agronomist.

Herbert A. Lunt, Ph.D., Assistant in Forest Soils.

Dwight B. Downs, General Assistant.

Paul J. Anderson, Ph.D., Pathologist in Charge.

T. R. Swan BaCK, M.S. Agronomist.

O. E. Street, M.S., Plant Physiologist.

Miss DoRothy LenARd, Secretary. 


\section{CONTENTS}

Part I The Nutritive Properties of Tobacco Seed . 609

Lafayette B. Mendel and Hubert Bradford Vickery

Part II The Globulix of Tobacco Seed ........... 625

Hubert Bradford Tickery, Alfred J. Wakeman and Charles S. Leavenworth

Part III Some Nitrogenot's Conponents of the Hot Water Extract of Fat-Free Tobacco Seed Meal

Hubert Bradford Tickery

Part IV A Microchemical Stedy of the Seed of Nicotiana Tabacta ................. 646

Florence A. McCormick 


\title{
CHEMICAL INVESTIGATIONS OF THE TOBACCO PLANT
}

\author{
III. TOBACCO SEED
}

\author{
PART I \\ THE NUTRITIVE PROPERTIES OF TOBACCO SEED
}

\section{Lafayette B. Mendel and Hubert Bradford Vickery}

Although every part of the tobacco plant has been reported to contain nicotine, this alkaloid could not be detected by Vickery and Pucher in the fully ripened seeds of Connecticut shade-grown tobacco by chemical methods (18). Ilyin (10), who has studied the distribution of nicotine in the plant, found that immature seed, and particularly the ovules at an early stage of development, contained appreciable proportions, but that as ripening progressed the alkaloid content diminished until finally none could be demonstrated. The physiological and chemical problems presented by this observation are of great interest, and, as a preliminary to their further study, it appeared desirable to verify the observations on the absence of nicotine from ripe tobacco seed by other than chemical methods. This seemed the more necessary inasmuch as nicotine can be easily detected in the sprouts and cotyledons of tobacco seed after only 9 to 11 days of germination.

In view of the well known toxic properties of nicotine the simplest physiological test for the presence of traces of this alkaloid in seed appeared to consist in conducting feeding trials on small animals; we therefore offered to albino rats a ration that consisted almost entirely of these seeds. Somewhat to our surprise the diet was consumed with avidity and without any evident untoward consequences. This observation gave rise to the present investigation.

Note: The investigations of tobacco described in the present bulletin were carried out as part of a general project under the title "Cell Chemistry", by the Department of Biochemistry of the Connecticut Agricultural Experiment Station, New Haven, Conn. The Department has enjoyed the benefit of the close coöperation of the Tobacco Substation. The expenses were shared by the Connecticut Agricultural Experiment Station and the Carnegie Institution of Washington, D. C. 


\section{FEEDING EXPERIMENTS WITH TOBACCO SEED}

\section{METHODS EMPLOYED}

The feeding experiments were of the conventional type long employed in this laboratory. Albino rats were used, the animals being kept in wire cages equipped with raised, false bottoms so as to prevent access to the feces. IVater was always available. Casual observations indicated that ingested intact seeds often passed through the alimentary tract apparently unaltered; the material

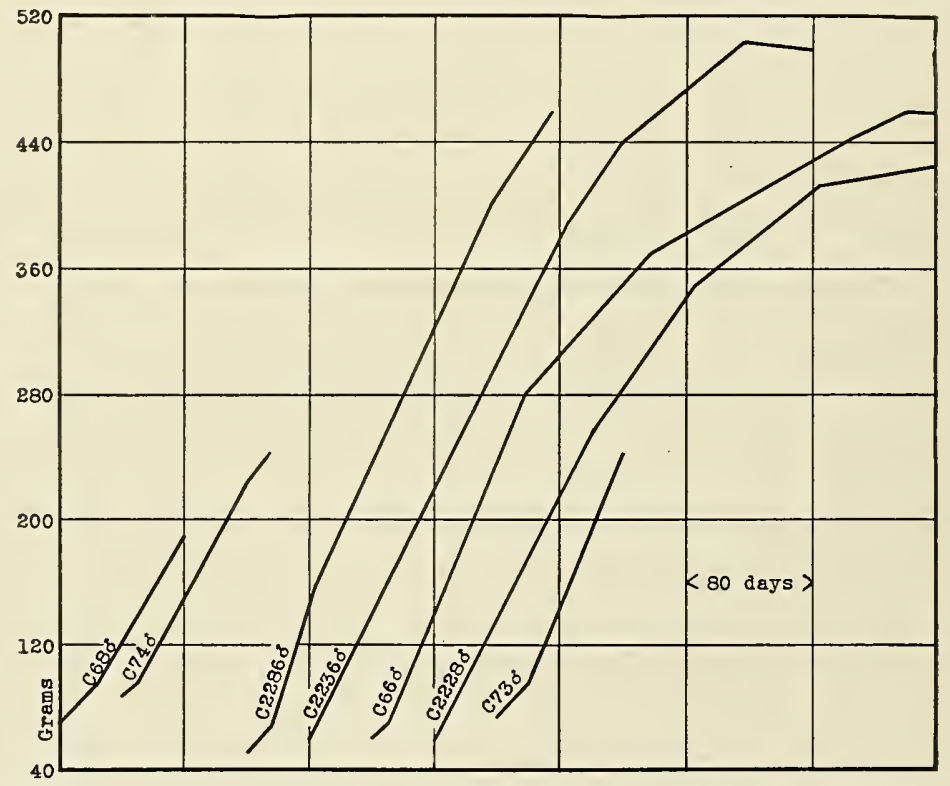

FIGURE 51. The rate of growth of albino rats on rations consisting almost exclusively of ground tobacco seed. The food mixtures used were as follows: for Rats C68 and C74, tobacco seed 98, salt mixture 2 per cent; for Rats C2286, C2236, C66, C2228 and C73, tobacco seed 98, salt mixture 2 per cent +10 drops cod liver oil daily.

was therefore customarily ground to an oily paste before being offered to the animals. In some instances ground seeds that had been freed from fat by extraction with organic solvents were employed in the rations.

\section{THE PILOT EXPERIMENTS}

Young male rats, 35 days of age and weighing 66 to $71 \mathrm{gm}$., were fed a mixture of ground tobacco seed $9 \$$ per cent, and Osborne-Mendel salt mixture IV (15) 2 per cent. The animals 
grew well for several weeks on this unusual food, as indicated by the graphs of gains in body weight in Figure 51 (Rats C68, C74).

In a number of preliminary experiments cod liver oil-a source of fat-soluble vitamins-was added as a daily supplement to the ration. Good growth was secured (Figure 51, Rats C2286, C2236, C66, C2228, C73). One male animal (Rat C66) on this unique ration reached a weight of $454 \mathrm{gm}$. in 374 days (see Figure 52).

The tobacco seed evidently supplies nearly all of the inorganic elements requisite for growth, as is indicated in Figure 53 by the records of Rats C81, C75, C94, C76. The sole food of these animals consisted of ground tobacco seed 99 per cent, $\mathrm{CaCO}_{3} 0.5$ per cent,

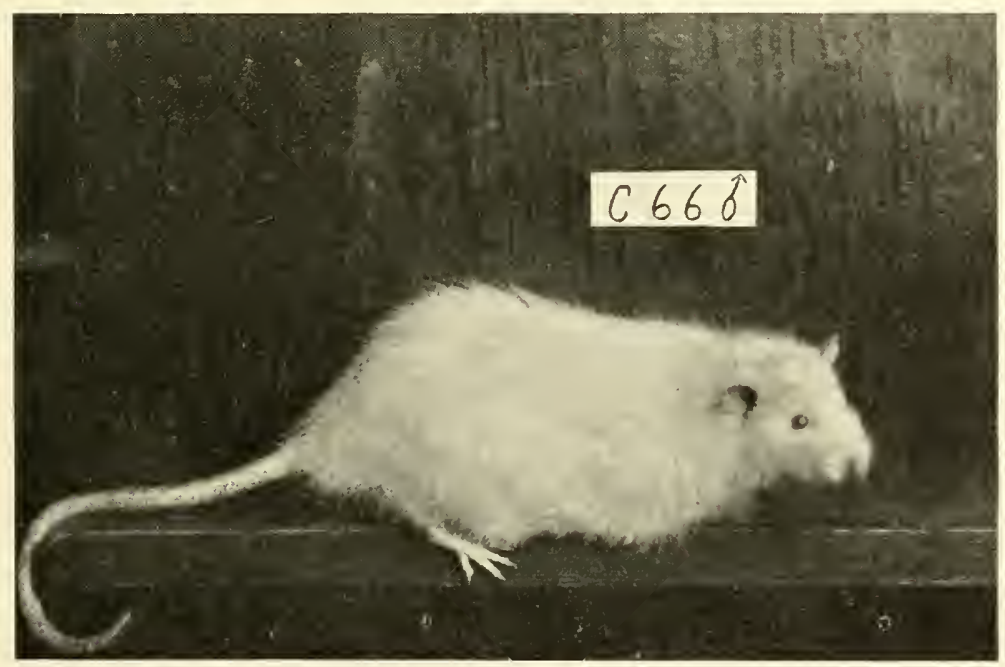

Figure 52. A rat that had been fed for 374 days, beginning at 35 days of age (63 gm. body weight) on a ration consisting of tobacco seed 98, salt mixture 2 per cent +10 drops cod liver oil daily. At the time the photograph was taken the animal weighed $454 \mathrm{gm}$.

and $\mathrm{NaC} 10.5$ per cent, with addition of 10 drops of cod liver oil daily in the case of the last two animals.

It is clear from these observations that tobacco seed yields all of the amino acids essential for growth, and that it contains vitamins $B$ and $G$ as well as the necessary inorganic elements, with the possible exception of calcium and chlorine.

\section{DOES TOBACCO SEED CONTAIN VITAMIN A?}

The answer to the question whether tobacco seed contains vitamin A has been sought in several ways. Curative and prophylactic tests were emoloyed with the whole (ground) seed, and cura- 
tive tests were conducted with the oil obtained therefrom. This fat, which may be expected to contain any fat-soluble vitamins present, was extracted from the ground seed by means of cold ether. The ether was then distilled off in the presence of carbon dioxide, the final traces being removed by warming the oil in a vacuum. The residual oil was kept in a refrigerator in dark colored, tightly stoppered bottles. The "tobacco seed oil," as we shall hereafter designate it, is pale yellow in color. It sometimes deposits a small amount of deeper colored sediment that has not yet been

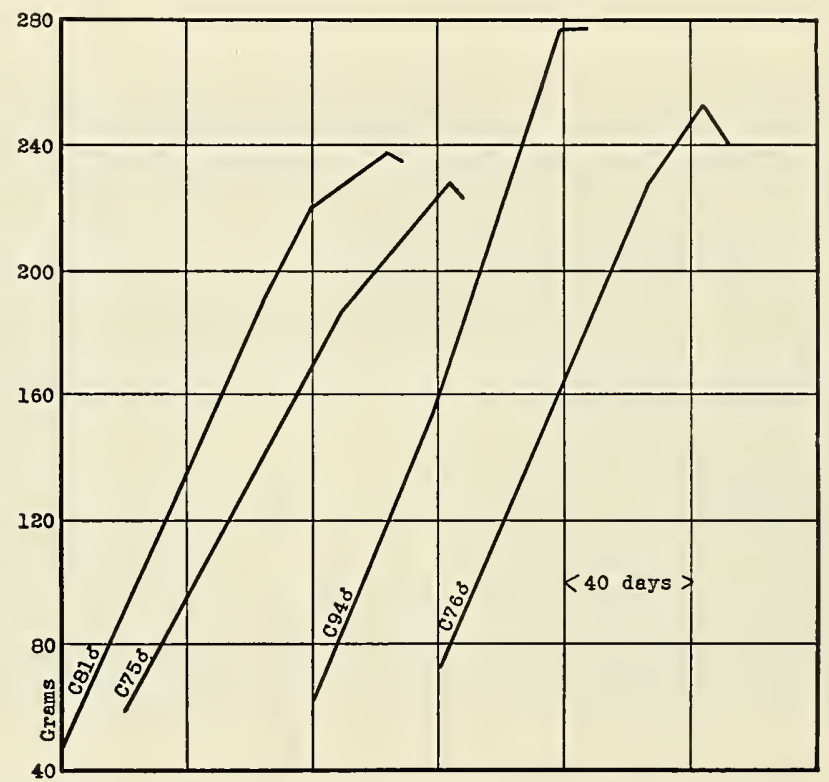

Figure 53. The rate of growth of rats on a ration in which tobacco seed supplied all of the requisite inorganic elements except those indicated in the small mineral supplements below. The food mixtures used were as follows: for Rats $\mathrm{C} 81$ and $\mathrm{C} 75$, tobacco seed $99, \mathrm{CaCO}_{3} 0.5, \mathrm{NaCl} 0.5$ per cent; for Rats $\mathrm{C} 94$ and $\mathrm{C} 76$, tobacco seed $99, \mathrm{CaCO}_{3} 0.5, \mathrm{NaCl} 0.5$ per cent +10 drops cod liver oil daily.

carefully examined. The clear, filtered oil, which Prof. W. E. Anderson of the Laboratory of Physiological Chemistry, Yale University, kindly examined for us, has the following chemical characteristics:

Specific gravity, $25^{\circ} / 25^{\circ}$

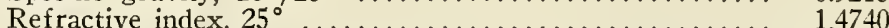

Saponification value .......................... 192.0

Iodine number (Hanus) of oil ................... 134.0

Iodine number (Hanus) of unsaturated fatty acids ..... 161.0 
Mixed saturated and unsaturated fatty acids ......... 93.2\%

Saturated fatty acids (corrected) ................. $9.7 \%$

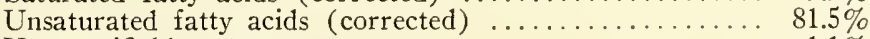

Unsaponifiable matter ......................... $1.1 \%$

A sample of ground seed was also extracted with hot alcohol and filtered. The extract was concentrated in vacuo to remove the alcohol, and was then treated with ether to dissolve the "fats." A sample of this oil, examined by Dr. Lucille L. Reed in our laboratory, gave an iodine number of 143.0.

\section{COLOR REACTIONS FOR VITAMIN A}

Dr. A. J. Wakeman of our laboratory examined the clear oil by the antimony trichloride reaction of Carr and Price (5), a procedure which is assumed by some investigators to indicate the presence of vitamin $A$. The deeply colored sediment referred to above was similarly examined. The results were negative in every instance. This does not necessarily imply that there is no physiological potency, however, for recent studies have repeatedly shown that carotinoid pigment, which fails to yield the antimony trichloride color reaction, may function like vitamin $A$ in the animal organism (14).

\section{ANIMAL TESTS FOR VITAMIN A}

A search for vitamin A was made in both the ground tobacco seed and in the oil extracted therefrom. Young male rats, approximating $60 \mathrm{gm}$. in body weight and selected from groups whose mothers had been kept on a regimen rather poor in vitamin $\mathrm{A}$, were supplied with a food mixture lacking vitamin $\mathrm{A}$ and composed of casein 18 per cent, salt mixture (15) 4 per cent, starch 54 per cent, and lard 24 per cent, with the addition of $0.2 \mathrm{gm}$. yeast and 0.001 $\mathrm{gm}$. viosterol daily. On this the animals developed unmistakable xerophthalmia in 35 to 140 days and exhibited a slowing, if not a cessation, of growth. When these signs of vitamin A deficiency were established various curative measures that involved the use of tobacco seed were instituted. In some cases the carefully preserved tobacco seed oil was fed, apart from the rest of the ration and usually admixed with the dried yeast, in doses not exceeding 25 drops $(665 \mathrm{mg}$.) per day. This corresponds to the oil in 1.56 $\mathrm{gm}$. of the seed. Even with these largest doses curative effects were not observed; nor was there any marked improvement in growth.

In other cases, when the deficiency symptoms became marked and benefit was not secured through administration of tobacco seed oil, the diet was changed to a mixture of 98 per cent of ground tobacco seed, plus inorganic salts. This tended to bring about recoveries. On the assumption of a daily food intake of only $5 \mathrm{gm}$. of the 


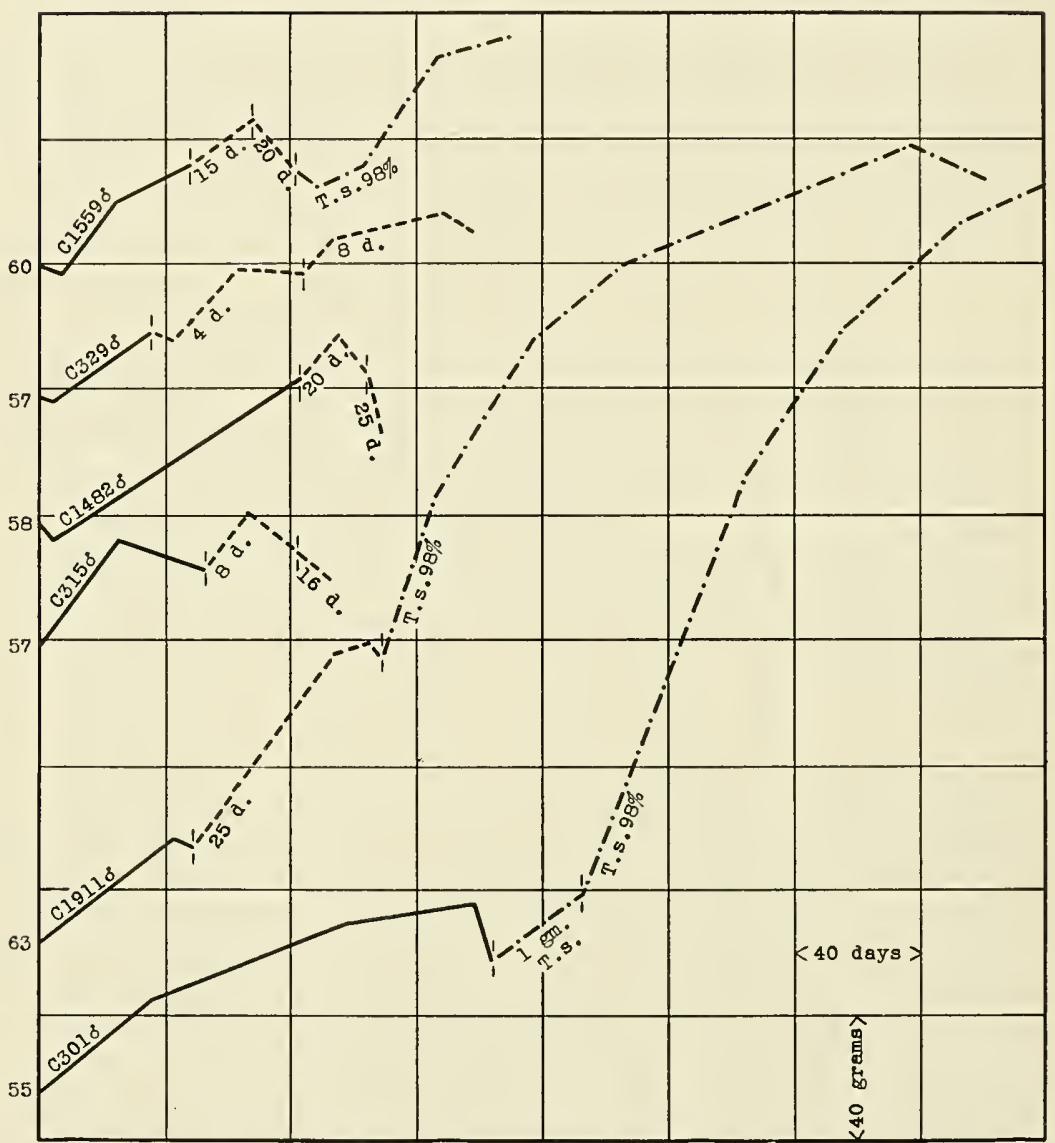

FIGURE 54. Experiments to test for the presence of vitamin A in tobacco seed and tobacco seed oil. During the first period of each experiment, indicated by the unbroken line, the animals were on an otherwise adequate diet devoid of vitamin A, and gave evidence of avitaminosis at the end of the period. Changes in the ration were then instituted as follows: in Period 2 Rats C1559, C329, C1482, C315, C1911 received a supplement of tobacco seed oil in varying amounts indicated on the graphs (d.=drops). In the subsequent periods the daily supplement of oil was either increased as indicated, or the diet was replaced by a mixture of tobacco seed 98 , salt mixture 2 per cent (T.s. 98 per cent). In the case of Rat C301 during the second period the supplement consisted of $1 \mathrm{gm}$. tobacco seed daily. In period 3 the diet was changed to the tobacco seed mixture indicated above. The effects are discussed in the text. 
tobacco seed food, the oil supplied in the seeds would exceed $2 \mathrm{gm}$. per day-a quantity far surpassing that which the rats would consume in extracted form. The effect on the growth rate was sometimes particularly striking (see Figure 54, Rat C301).

Recovery from deficiency symptoms occurred also on diets in which the quantity of tobacco seed was limited to one-half the food mixture.

There are other biological phenomena that serve as indications of lack of vitamin A in a food. In 1922 Evans and Bishop $(7,8)$ noted a new and characteristic test for deficiency in fat-soluble vitamin $\mathrm{A}$ - the constant appearance of cornified cells either predominantly or exclusively in the vaginal smear. This is in marked contrast to the orderly succession of different cell types that are thrown off within the vagina of rats under conditions of perfect nutrition and a normal oestrous cycle. According to Evans inadequacy of vitamin $\mathrm{A}$ injures the female reproductive system so that fertilization and implantation take place but resorption follows.

An investigation of the possible occurrence of vitamin $\mathrm{A}$ in tobacco seed by means of the delicate index of its possible influence on the vaginal epithelium has been carried out with the helpful coöperation of Dr. S. D. Aberle of the Yale University School of Medicine. Preliminary tests were undertaken on the efficiency of the procedure in which microscopic examination of the cells secured through vaginal smears was made by expert observers. In 40 female rats on diets deficient in vitamin $\mathrm{A}$ the continual succession of cornified vaginal cells preceded either loss of weight or signs of xerophthalmia. In three ovariectomized animals, after an average of 73 days on the A-deficient diet, continual cornified cells were present in the vagina. Yet cornified cells have never been found in the vagina of ovariectomized rats on diets that contain adequate supplies of vitamins. The changed picture of the vaginal epithelium is a result of the dietary deficiency and is not related to ovarian function.

In the new experiments female rats were kept upon diets that contained different proportions of tobacco seed, to ascertain whether the food supplied sufficient vitamin A to prevent continual cornification of the vagina. Eight rats ranging in age from 28 to 37 days were divided into two groups. The first group of four animals was put on a ration which contained ground tobacco seed 50 per cent, casein 15 per cent, salt mixture (15) 3 per cent, lard 10 per cent, starch 22 per cent; $0.2 \mathrm{gm}$. of yeast and $0.001 \mathrm{gm}$. viosterol were fed daily (Diet I). Four rats were given food consisting of tobacco seed 98 per cent and salt mixture 2 per cent (Diet II). In both groups food and water were kept continually in the cages.

The animals were observed two or three times a week, at first to determine the date of the opening of the vagina, and subse- 
quently to take samples of the vaginal cells. The animals on Diet I, which contained yeast and viosterol, gained weight more rapidly; the vaginas opened earlier and continual cornified cells were present in the vagina sooner than in the animals on Diet II. Although there was an average difference of 42.5 days in the opening of the vagina of the two groups, the average weight for both groups at the time the vagina opened was approximately the same.

No marked soreness of the eyes (xerophthalmia) developed in the rats on either Diet I or Diet II. Diet II did not produce as good growth as Diet I. The average ages at which the rats on the 50 per cent and the 98 per cent tobacco seed diets showed continual cornified vaginal cells were 101 and 125 days respectively. The delay of 24 days in the group on 98 per cent tobacco seed indicates a higher content of vitamin $\mathrm{A}$ in the latter diet. The vitamin $\mathrm{A}$ content of the 98 per cent tobacco seed, however, was not sufficient to change the character of the vaginal cells in rats that had been reared on 50 per cent tobacco seed diets, once the condition had become established, nor yet to prevent the continual appearance of cornified cells in the vaginas of rats on that diet. In every instance ingestion of two drops of cod liver oil daily changed the vaginal picture within a few days.

The upshot of our own tests seems to us to indicate the occurrence of vitamin A potency in low concentration in tobacco seed. This would account for the occasional slow recoveries from the effects of vitamin A deficiency that were observed.

\section{ANIMAL TESTS FOR VITAMINS B AND G}

The preliminary experiments demonstrated that rats grew satisfactorily on a diet in which tobacco seed furnished the sole source of those food factors formerly designated as vitamin $\mathrm{B}$ (or the vitamin $\mathrm{B}$ complex). This result implies that the seed contains what are now distinguished as vitamins $B$ (antineuritic) and $G$ (antipellagric) and further suggests that the third component of the complex, claimed to exist by some investigators, is also present (see Figure 51).

Tobacco seed can be shown in other ways to contain vitamins $\mathrm{B}$ and $\mathrm{G}$. Relatively small daily quantities $(0.2 \mathrm{gm}$.) of the fat-free seed supplement autoclaved yeast (a source of the more thermostable vitamin G) (Figure 55); but when fat-free seed is autoclaved for 4 hours at $100^{\circ}$ temperature and 15 pounds pressure, it will no longer supplement autoclaved yeast (Figure 55). The presence of the thermolabile vitamin B in the seed is thus further established.

In order to secure some idea of the relative abundance of vitamins $B$ and $G$ in tobacco seed a few quantitative experiments were carried out. Two types of "basal" rations were used, like those of Chase (6) and Bourquin (4), described by Quinn, Whalen and 


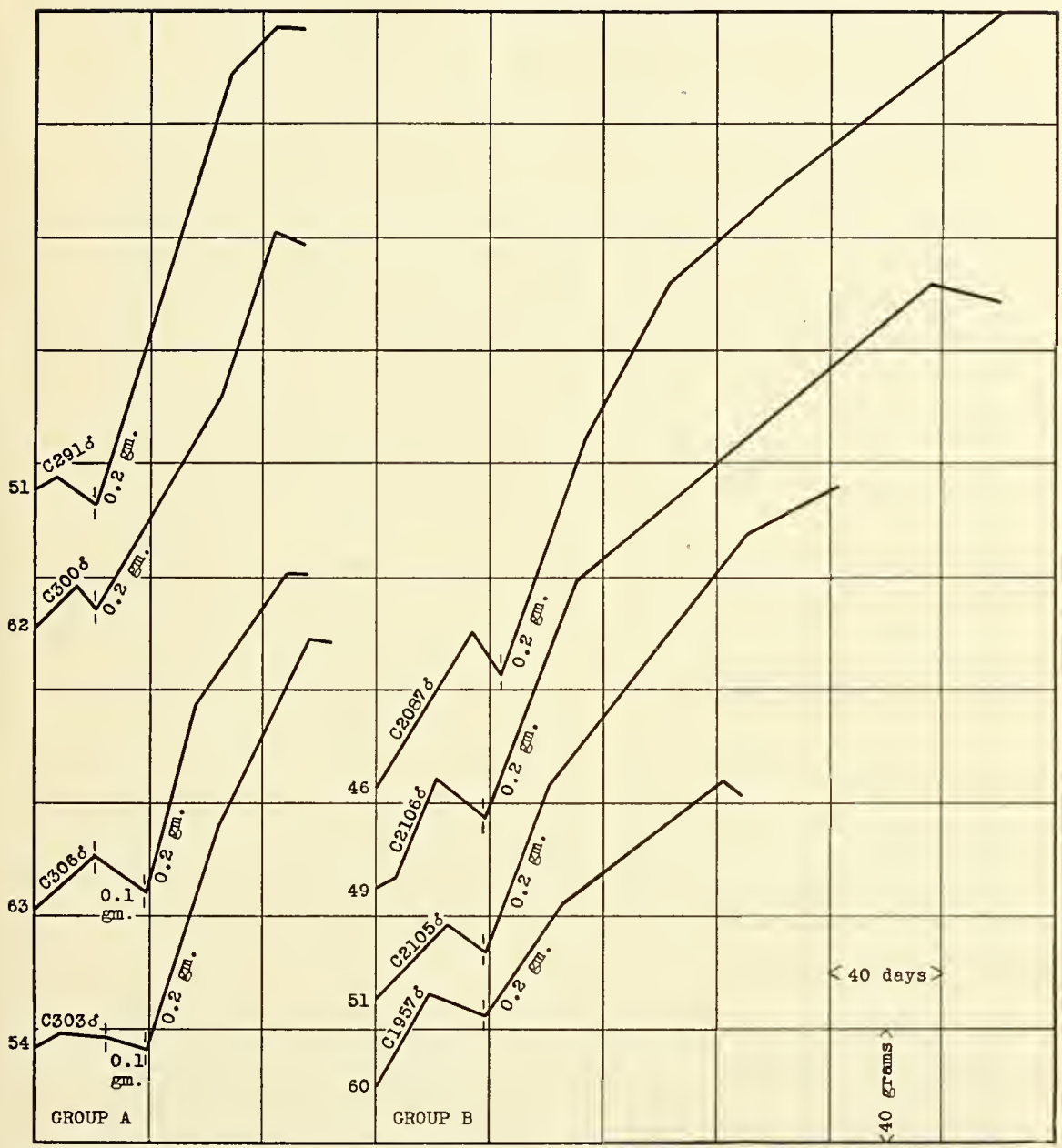

FIgURE 55. Evidence for the presence of vitamin $B\left(B_{1}\right)$ in tobacco seed. In Group A the four animals received, during the first period, a basal diet supplemented with autoclaved yeast (a source of the more thermostable vitamin $G$ ). When failure of growth resulted, the animals received additional supplements of fat-free tobacco seed in Periods 2 and 3 . The amount of the daily supplements is indicated in grams. Growth was promptly restored when the supplement of tobacco seed amounted to $0.2 \mathrm{gm}$.

In Group B the four animals received during Period 1 a mixture of autoclaved yeast (a source of vitamin $G$ ) and autoclaved fat-free tobacco seed. The cessation of growth indicates the destruction of vitamin $\mathrm{B}$ in the seed by heating. When the autoclaved fat-free tobaccoseed was replaced in Period 2 by a daily supplement of $0.2 \mathrm{gm}$. unheated fat-free tobacco seed, growth was promptly restored, indicating anew the potency of the tobacco seed in vitamin $B$. 
Hartley (16). The B-free ration consists of casein 18 per cent, autoclaved yeast 15 per cent, cornstarch 53 per cent, butter fat 8 per cent, cod liver oil 2 per cent, salt mixture (15) 4 per cent; the G-free ration consists of casein 15 per cent, whole wheat 20 per cent, cornstarch 51 per cent, salt mixture (15) 4 per cent, butter fat 8 per cent, and cod liver oil 2 per cent. Young rats were kept on one or the other of these deficient rations until they began to decline in body weight; daily supplements of weighed amounts of ground tobacco seed-0.25 gm., $0.5 \mathrm{gm}$., or $1.0 \mathrm{gm}$. respectively-were then supplied for periods of 35 days. Two male rats were used for each comparison. The outcome was as follows:

$\begin{array}{cc}\text { Test of Tobacco SeEd for } & \text { Vitamin B } \\ \begin{array}{c}\text { Daily supplement to } \\ \text { B-free ration }\end{array} & \begin{array}{c}\text { Average daily gain } \\ \text { in body weight }\end{array} \\ \text { gm. } & \text { gm. } \\ 0.25 & 2.8 \\ 0.5 & 3.7 \\ 1.0 & 3.8\end{array}$

$\begin{array}{cc}\text { Test of Tobacco Seed for } & \text { Vitamin G } \\ \begin{array}{c}\text { Daily supplement to } \\ \text { G-free ration }\end{array} & \begin{array}{c}\text { Average daily gain } \\ \text { in body weight }\end{array} \\ \text { gm. } & \text { gm. } \\ 0.25 & 1.3 \\ 0.5 & 1.7 \\ 1.0 & 2.6\end{array}$

It is apparent that tobacco seed is relatively richer (in terms of conventional unitage) in vitamin $B$ than in vitamin $G$.

\section{VITAMIN D}

Preliminary tests for the presence of vitamin $\mathrm{D}$ in tobacco seed were conducted on animals reared on a diet that consisted of corn $685 \mathrm{gm}$. , gluten flour $180 \mathrm{gm}$. , sodium chloride $10 \mathrm{gm}$., calcium carbonate 8.69 gm., disodium phosphate (hydrated) 116 gm., supplemented by the daily administration of $0.1 \mathrm{gm}$. butter fat, $0.5 \mathrm{gm}$. tobacco seed oil, and $0.2 \mathrm{gm}$. of a mixture of yeast, calcium carbonate and starch in the ratio of $100: 0.9: 13.1$. This diet was made so as to contain calcium and phosphorus in the ratio of $0.3: 1.0$. The control animals received a supplement of corn oil. The ribs and forelegs of the animals were kindly examined for us by Dr. E. A. Park of the Johns Hopkins University. Although this diet was not one upon which rickets is readily produced, the absence of any notable difference between the bones of the two lots of animals permitted the tentative conclusion that tobacco seed does not contain any antirachitic agent. 


\section{BREEDING TESTS-VITAMIN E-LACTATION}

Various causes of sterility in male and female mammals are recognized today. A regimen may be adequate in so far as one can judge from the growth, somatic appearance, and evident wellbeing of animals; yet they may fail to produce offspring. Slight changes in the dietary often result in securing successful pregnancy, parturition and lactation. Thus the need of a specific accessory food factor to insure normal reproduction in animals has been definitely demonstrated for the rat $(9,11,12,13)$. The essential substance is designated vitamin $\mathrm{E}$. Lack of it leads to degenerative changes in the testes of the male; vitamin $\mathrm{E}$ is needed "not only for the multiplication but also for the very existence of the germ cells themselves." In the female, oestrus, copulation, ovulation, fertilization, tubal journey, and implantation occur, but pregnancy is interrupted when there is a depletion of vitamin $\mathrm{E}$. Dietary sterility has thus come to have a recognized standing. Infertility does not give conclusive evidence of the deficiency. Successful mating, however, offers assurance that the dietary requisites have been supplied-particularly when the breeding tests are conducted under circumstances that bring about an exhaustion of previously acquired "stores" of vitamin E. Dietary sterility once established in the male is not readily cured; in the female the capacity to bear young can frequently be restored.

Our breeding experiments have been conducted with rats for which tobacco seed supplied the sole source of vitamin $E$ after the time of weaning. Both males and females were reared on a diet that consisted of tobacco seed 98 per cent and salt mixture (15) 2 per cent ; 10 drops cod liver oil were also administered daily. The salt mixture was added to avert the possible inorganic deficiencies of unsupplemented tobacco seed. Cod liver oil, in the proportions used, has been demonstrated by Evans and Burr, as well as in this laboratory, to be devoid of effective quantities of vitamin $\mathrm{E}$; it was furnished to the animals in order to insure an adequate intake of vitamins $\mathrm{A}$ and $\mathrm{D}$. The pathological changes induced in the female genital tract, when there is a shortage of vitamin $A$, have already been mentioned.

Out of fourteen matings of rats thus reared to maturity, only a single instance of failure of reproduction was noted; 104 young were actually counted. This means an average of 7 young per litter-a figure identical with the average for our colony.

Much difficulty was experienced in rearing the litters because so many of the young were eaten by their mothers. This is, however, by no means a consequence attributable specifically to the tobacco seed diet, for it is an occasional complaint among breeders, even in "stock" colonies. Lactation also was far from satisfactory. It was found that addition of a small amount of yeast to the diet of 
the young resulted in better gains in weight. The requirement of vitamin $\mathrm{B}$ is known to be high during lactation, and milk is frequently relatively poor in this factor. We suspect, therefore, that the mammary secretion of the mother rats was not such as to permit optimal growth of the suckling young.

Improvement was secured in some instances by attempting a concentration of the water soluble vitamins in the tobacco seed diet through elimination of part of the fats therein. It will be recalled that the fats amount to nearly half the weight of the seed. Ground tobacco seed was accordingly extracted with gasoline and ether and much of the "fat" removed. When the "extracted tobacco seed meal," correspondingly enriched in the residual vitamins B and $G$, was fed in place of the usual tobacco seed meal some improvement in the growth of the young was secured. The gains of the young were, however, never up to average, and they could be increased by the addition of yeast to the ration. However, three females of the "second generation" of rats that were fed exclusively on tobacco seed, inorganic salts and cod liver oil, and were mated to males fed on this diet from the time of weaning, gave birth to litters of 8 to 10 "third generation" young. The occurrence of vitamin $\mathrm{E}$ in tobacco seed is thus established beyond question.

Incidentally, the rearing of a third generation of animals on a diet in which so many of the requisites for growth and reproduction were supplied by a single seed is noteworthy from the standpoint of animal nutrition and feeds. It is not unlikely that many other seeds, some of them designated as "weed seeds" and carefully excluded from commercial feeds may possess unanticipated nutrient values.

\section{THE FAT OF RATS FED ON TOBACCO SEED RATIONS}

In an elaborate study of the effects of diet upon the body fat of albino rats, Anderson and Mendel (1) observed that, in some instances, the resulting fat, judged by the iodine number, resembled that which was ingested. This was notably true for rations rich in soy bean, maize, cottonseed, and peanut oils. In the case of other food fats striking differences were found in the deposited body fats. The present investigation afforded an opportunity to examine the depot fat of two male rats that had been kept on a ration consisting of tobacco seed 98 per cent and salt mixture (15) 2 per cent, with 10 drops cod liver oil administered daily. This represented an intake in which considerably more than half of the energy was derived for a long period from tobacco seed fat (iodine number ca. 143). The fat removed from the subcutaneous, perirenal and genital regions ${ }^{1}$ showed small variations in iodine numbers ranging from 133 to 138 , according to analyses made for us by Dr. Lucille L.

\footnotetext{
${ }^{1}$ The fats were prepared as described by Reed, Yamaguchi, Anderson and Mendel (17).
} 
Reed. Evidently the tobacco seed oil was influential in producing the deposition of an even more unsaturated fat than that stored by rats that had ingested large amounts of very unsaturated oils such as soy bean oil and corn oil (iodine numbers of fat from rats on these oils were 122 and 112 respectively (1)). Rats forced to synthesize fat from a diet high in carbohydrate stored a much less unsaturated fat with an iodine number of 60 .

\section{EXPERIMENTS ON MICE}

In order to extend these experiments to another species a few feeding experiments were made for us by Prof. W. E. Anderson of Yale University on brown mice. The nutritive requirements of albino mice have been discussed in detail by Beard (2) and by Bing (3). Our mice were weaned at 23 days of age and thereafter were kept on a ration consisting of tobacco seed 98 per cent, salt mixture (15) 2 per cent. Growth continued satisfactorily until the tests were discontinued at the end of 151 days, long after the animals had reached adult size, 31 and $32 \mathrm{gm}$. respectively.

These records confirm the value of tobacco seed as a nutrient notable in so far as its protein and water soluble vitamins are concerned. There is no reason to assume that other mammalian species would not derive nutriment equally well from the seeds, provided that the latter are satisfactorily disintegrated.

\section{EXPERIMENTS ON PIGEONS}

A few experiments on pigeons, conducted for us by Prof G. R. Cowgill of Yale University, have given unequivocal evidence that tobacco seed is non-toxic for this species also and that, even when unsupplemented with water soluble vitamins or other proteins, it can meet the requirements of these birds with respect to the food essentials indicated. Two pigeons weighing respectively 281 and $312 \mathrm{gm}$. were given polished rice ad libitum and a gelatin capsule containing the dried residue of hot water extracted muscle (socalled "meat residue"), a small quantity of the Osborne-Mendel salt mixture (15), and a small allowance of cod liver oil daily over a period of 12 days. At the end of this time they had declined in body weight to 238 and $279 \mathrm{gm}$. respectively - a result clearly due, as indicated by curative tests in other experiments on the same birds, to a shortage of the antineuritic vitamin $B$. The ration was then changed to about 15 capsules containing approximately $1 \mathrm{gm}$. each of whole tobacco seed daily, the intake varying from 15 to 14 $\mathrm{gm}$. for the smaller pigeon and 17 to $16 \mathrm{gm}$. for the larger one. Chicken "grit" and water were always available. On this regimen the pigeons promptly began to gain in weight, reaching 304 and 346 gm. respectively when the feeding tests with the seed were termi- 
nated after 22 days. Some apparently intact seeds were observed from time to time in the excreta, but the amounts were always small.

\section{EXPERIMENTS ON CHICKENS}

An experiment was conducted for us by Prof. Walter Landauer of Storrs Agricultural Experiment Station in which a diet made up of tobacco seed 94 per cent, cod liver oil 2 per cent, calcium carbonate 2 per cent, sodium chloride 1 per cent, and salt mixture (15) 1 per cent, was fed to chickens. Two lots of 26 chicks each were confined in separate parts of an experimental brooder, one lot being furnished a standard chicken mash to serve as a control. At the end of 4 weeks, crushed oyster shells were placed before both lots of birds, and the tobacco seed in the experimental diet was ground to a paste before being mixed with the cod liver oil.

Table 1. The Average Weight of Chickens Fed on a Tobacco Seed Diet and on a Standard Chicken Mash

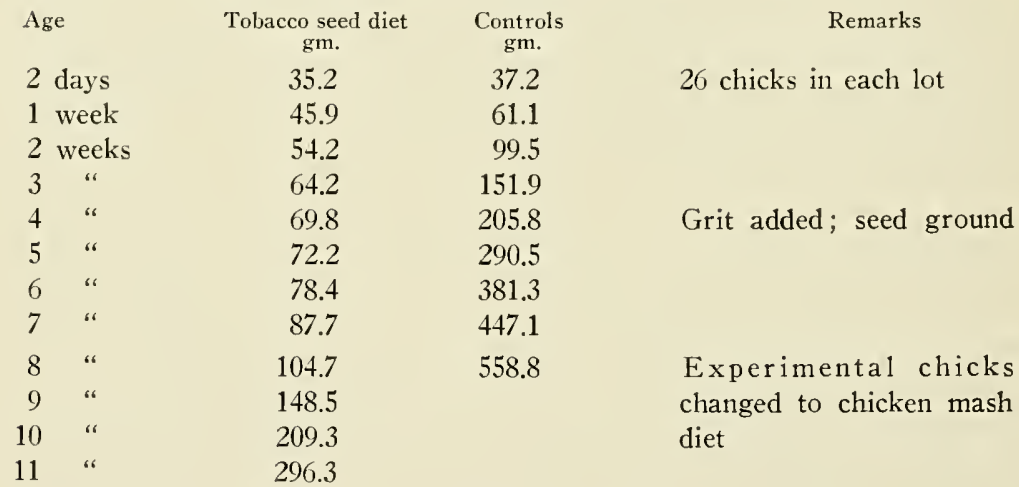

The data in Table 1 show the relative rates of growth of the birds on the two diets in terms of the average weight of each lot. The rate of growth on the experimental diet was very slow but the prompt resumption of growth when the experimental diet was replaced by standard chicken mash and the general healthy aspect of the animals throughout the experiment showed clearly that tobacco seed contains no factor toxic to chickens. The diet selected, however, was obviously not satisfactory for the growth of this species.

Experiments were also conducted by us in which groups of six chicks were fed on the following experimental diets: 
1. Extracted tobacco seed ........... 94 per cent Salt mixture ${ }^{1} \ldots \ldots 4$ per cent Cod liver oil ....... 2 per cent

2. Extracted tobacco seed ..........4 47 per cent Cornstarch ......4 47 per cent Salt mixture ..... 4 per cent Cod liver oil ....... 2 per cent
3. Ground tobacco seed 94 per cent Salt mixture ...... 4 per cent Cod liver oil ...... 2 per cent

4. Ground tobacco seed 48 per cent Chicken mash ..... 50 per cent E. Cod liver oil ...... 2 per cent

A control group received a standard chick feed fortified with 2 per cent by weight of cod liver oil. In no case was the growth rate of the chickens fed upon tobacco seed satisfactory. The diet in which the oil of the seed had been replaced by cornstarch gave a slow steady growth at a rate of approximately one-quarter of that of the control animals. The growth rate on the mixture of tobacco seed and mash was about the same, but the animals on the other diets grew very slowly and most of the chicks fed on the extracted seed diet died. Daily records of the amount of food eaten by the various groups show very poor consumption of the tobacco seed diets. This suggests that the factor limiting the growth of the birds was the small intake of food, possibly owing to a taste that they found unpleasant. This factor, of course, played no part in the experiments on pigeons since force feeding was resorted to in that case.

A tentative conclusion only can be drawn from these admittedly incomplete experiments; it seems, however, that diets in which tobacco seed forms a substantial part of the ingested food are not satisfactory for young chickens under the conditions of our experiment. No experiments on mature fowl have been attempted.

\section{SUMMARY}

Feeding trials on albino rats have shown that this species can be successfully raised to maturity at a satisfactory rate of growth, and can reproduce, on a diet that consists almost exclusively of tobacco seed. Either 1 or 2 per cent of inorganic salts was added, and a few drops of cod liver oil were administered daily. This was essential to successful growth because of the deficiency of the seed in vitamins $\mathrm{A}$ and $\mathrm{D}$.

Experiments designed to provide evidence of the presence of vitamin $\mathrm{A}$ in the seed were somewhat inconclusive. It is certain that the seed does not contain a concentration of this vitamin adequate for successful growth or for complete protection against xerophthalmia. It is probable, however, that the vitamin is not entirely absent.

${ }^{1}$ The salt mixture used in these experiments was composed of 4 parts of the OsborneMendel salt mixture (15), 1 part of sodium chloride, and 1 part of calcium carbonate. 
Vitamins $B$ and $G$ were present in tobacco seed in quantities adequate for growth and well-being. Under circumstances of unusual demand for vitamins $B$ and $G$, as, for example, during lactation, a moderate degree of deficiency was apparent.

Although no final conclusion can yet be drawn it is probable that tobacco seed is almost, if not entirely, deficient in vitamin $D$.

Vitamin $\mathrm{E}$ is present in tobacco seed in quantities adequate to provide for reproduction and to protect both sexes from physiological changes due to a deficiency of this factor.

Experiments on mice and on pigeons have demonstrated the nontoxicity of the tobacco seed for other species; likewise the good nutritive value of the proteins in the seed. The seed also supplied the water-soluble vitamins needed by mice, and functioned as an effective antineuritic agent (proof of vitamin B) for pigeons.

The success of these feeding experiments demonstrates that the total protein of this seed is of exceptionally good biological quality; in this respect it resembles the proteins of other oil seeds for which experimental data have been obtained.

A few experiments on young chickens showed that tobacco seed is not a satisfactory source of nutriment for this species.

\section{BIBLIOGRAPHY}

1. Anderson, W. E., and Mendel, L. B., Jour. Biol. Chem., 76: 729. 1928.

2. Beard, H. H., Amer. Jour. Physiol., 75: 645, 658, 668, 682. 1926.

3. Bing, F. C., and MENDEL, L. B., Jour. Nutr., 2: 49. 1929.

4. Bourquin, A., and Sherman, H. C., Jour. Amer. Chem. Soc., 53: 3501. 1931.

5. CARr, F. H., and Price, E. A., Biochem. Jour., 20 : 497. 1926.

6. Chase, E. F., and Sherman, H. C., Jour. Amer. Chem. Soc., 53: 3506. 1931.

7. Evars, H. M., Jour. Biol. Chem., 77 : 651. 1928.

8. Evans, H. M., and Bishop, K. S., Anat. Rec., 23: 17. 1922.

9. Evans, H. M., and Burr, G. E., The Antisterility Vitamine Fat Soluble E, Calif. Univ. Mem., 8: 1. 1927.

10. Ilyin, G., U. S. S. R. State Inst. Tobacco Investigations, Bul. 57 (in Russian). 1929.

11. Mason, K. E., Nat1. Acad. Sci. Proc, 11: 377. 1925.

12. MAson, K. E., Jour. Expt. Zool., 45: 159. 1926.

13. Mason, K. E., Jour. Nutr., 1: 311. 1929.

14. MOORE, T., Biochem. Jour., 24: 692. 1930.

15. Osborne, T. B., and Mendel, L. B., Jour. Biol. Chem., 37 : 572.1919.

16. Quinn, E. J., Whalen, F. B., and Hartley, J. G., Jour. Nutr., 3 : 257. 1930.

17. Reed, L. L., Yamaguchi, F., Anderson, W. E., and Mendel, L. B., Jour. Biol. Chem., 87: 147., 1930.

18. Vickery, H. B., and Pucher, G. W., Conn. Agr. Expt. Sta., Bul. 311 : 234. 1930 . 


\section{PART II \\ THE GLOBULIN OF TOBACCO SEED}

\section{Hubert Bradford Vickery, Alfred J. Wakeman and Charles S. Leavenworth}

The few studies of the seed of the tobacco plant that have been published refer chiefly to the oil and to the availability of the oil-free residue for fertilizer or for animal feeding $(6,7)$. Ilyin (3) and Vickery and Pucher (10) have given brief reports of the distribution of nitrogen in this seed, but apparently no particular attention has been paid to the proteins that it contains.

The seeds employed in the present investigation were those of Connecticut shade-grown tobacco; they are brown in color, the testa being somewhat rough or pebbled. The seeds are ellipsoidal in shape, frequently flattened from the close packing in the capsule, and very small, 100 of them weighing only $0.009 \mathrm{gm}$. A histological study of the seeds carried out by Dr. McCormick of the Department of Botany forms Part IV of this Bulletin.

A proximate chemical analysis of two lots of tobacco seed, derived from different crops, is given in Table 2.

Table 2. Proximate Analysis of Tobacco Seed on Air-Dry Basis

$\begin{array}{lcc} & \begin{array}{c}1929 \mathrm{crop} \\ \text { per cent }\end{array} & \begin{array}{c}1930 \mathrm{crop} \\ \text { per cent }\end{array} \\ \text { Moisture } & 3.34 & 6.87 \\ \text { Ash } & 3.71 & 3.31 \\ \text { Total nitrogen } & 3.89 & 3.67 \\ \text { Crude protein (N x 5.34) } & 20.76 & 19.60 \\ \text { Crude fiber } & 14.44 & 14.20 \\ \text { Carbohydrate } & & \\ \text { Water soluble after acid hydrolysis } & & \\ \quad \text { (as dextrose) } & 3.08 & 2.13 \\ \text { Water insoluble after hydrolysis } & & \\ \quad \text { (as dextrose) } & 0.55 & 1.31 \\ \text { Starch } & 0.00 & 0.00 \\ \text { Ether extract } & 42.23 & 43.10 \\ \text { Undetermined } & 11.89 & 9.48\end{array}$

The fat content of this seed is extraordinarily high and its accurate determination presents considerable difficulty. The figures given represent the weight of the ether extract after being dried in a hot water oven. The specimen of the seed taken had been previously dried in a vacuum oven for several hours, or until no more water was removed. The extraction was conducted with absolute ethyl ether in a continuous percolation apparatus for 16 hours; 
subsequent extraction for 16 hours gave an insignificant additional quantity of fat.

An appreciably higher apparent fat content was observed when samples of ground seed that were dried in a vacuum desiccator over sulfuric acid were extracted with absolute ethyl ether for 4 days in a modified Soxhlet apparatus. The fat was then dried in a vacuum desiccator over sulfuric acid. Under these conditions as much as 48.0 per cent of crude fat could be obtained while, if ordinary ether were used for extraction, 50.6 per cent was secured.

For the preparation of the protein a convenient quantity of seed was ground in a poppy seed mill and the paste-like mass was extracted twice successively with light gasoline. The meal was filtered off and the residual gasoline was removed by washing with ether; the meal was then dried in thin layers on pans at room temperature. The product was of a gray-brown color; a typical specimen from the 1929 crop contained 6.35 per cent of moisture and only a trace of fat. The nitrogen content, calculated moisturefree, was 6.74 per cent. A specimen from the 1930 crop contained 8.81 per cent moisture and 7.37 per cent nitrogen, calculated moisture-free.

\section{EXTRACTION OF THE SEED MEAL}

A preliminary experiment showed that 72.4 per cent of the nitrogen of the meal could be extracted by thorough treatment with molar sodium chloride solution. The residual nitrogen was then extraordinarily resistant to the action of solvents; cold $0.05 \mathrm{M}$ sodium hydroxide removed only 1.3 per cent more of it and cold $0.05 \mathrm{M}$ sodium hydroxide in 70 per cent alcohol only an additional 0.4 per cent. The residue was heated at boiling temperature with $0.05 \mathrm{M}$ sodium hydroxide in 70 per cent alcohol, but even this ordinarily extremely effective solvent removed only 4.7 per cent of nitrogen from the residue; more than 12 per cent of the nitrogen of the seed resisted all efforts at extraction. The details of another extraction experiment are shown in Table 3.

The first extraction with molar sodium chloride was conducted by repeatedly grinding the fat-free seed through a small plate mill with the solvent and then shaking by machine for several hours; a little toluene was also added. The opalescent extract was centrifuged off and filtered through a thick pad of paper pulp. On dialysis, 88.5 per cent of the nitrogen of this extract separated in a form that appeared to be protein. The subsequent extracts were prepared by shaking the meal with the solvent for several hours. The saline extracts were opalescent and were filtered clear on pulp before sampling for analysis; the first alkaline extract was also turbid, the others were clear. The extractions with hot alkaline alcohol were conducted at boiling temperature under a reflux con- 
denser for 3 and 2 hours respectively. The somewhat large loss of nitrogen can be accounted for by the filtration of the turbid saline extracts before sampling and also by loss of ammonia during the alkali extractions.

Table 3. Extraction of Nitrogen from Ground Fat-Free Tobacco Seed (1930 CROP)

\begin{tabular}{|c|c|c|c|c|}
\hline $\begin{array}{l}\text { Weight of seed taken }=74.4 \\
\text { Solvent }\end{array}$ & $\begin{array}{l}\mathrm{gm} . \\
\text { Volume }\end{array}$ & $\begin{array}{l}\text { Nitroge } \\
\text { Reaction }\end{array}$ & $\begin{array}{l}=5.00 \\
\text { Nitrogen } \\
\text { extracted }\end{array}$ & $\begin{array}{l}\text { Total } \\
\text { nitrogen } \\
\text { of seed }\end{array}$ \\
\hline $\begin{array}{c}1.0 \mathrm{M} \text { sodium chloride } \\
\text { ". }\end{array}$ & $\begin{array}{r}c c . \\
2000 \\
800 \\
700\end{array}$ & $\begin{array}{l}\mathrm{pH} \\
6.1 \\
6.4 \\
6.5\end{array}$ & $\begin{array}{l}\text { gm. } \\
3.208 \\
0.340 \\
0.0837\end{array}$ & $\begin{array}{l}\text { per cent } \\
64.16 \\
6.81 \\
1.67\end{array}$ \\
\hline Water & 1060 & & 0.0188 & 0.38 \\
\hline $0.05 \mathrm{M}$ sodium hydroxide, cold & $\begin{array}{r}1000 \\
750\end{array}$ & & $\begin{array}{l}0.0584 \\
0.0277\end{array}$ & $\begin{array}{l}1.17 \\
0.55\end{array}$ \\
\hline $\begin{array}{r}0.05 \mathrm{M} \text { sodium hydroxide in } 70 \% \\
\text { alcohol, cold }\end{array}$ & $\begin{array}{l}1100 \\
1000\end{array}$ & & $\begin{array}{l}0.0342 \\
0.005\end{array}$ & $\begin{array}{l}0.68 \\
0.10\end{array}$ \\
\hline $\begin{array}{l}0.05 \mathrm{M} \text { sodium hydroxide in } 70 \% \\
\text { alcohol, hot } \\
\text { Residue } \\
\text { Loss }\end{array}$ & & & $\begin{array}{l}0.329 \\
0.070 \\
0.445 \\
0.379\end{array}$ & $\begin{array}{l}6.59 \\
1.41 \\
8.91 \\
7.57\end{array}$ \\
\hline
\end{tabular}

This, and several similar experiments, showed that, in general, about 80 per cent of the nitrogen of tobacco seed could be brought into solution by suitable solvents. Most of the extracted nitrogen is undoubtedly protein; and that a considerable part of the insoluble nitrogen also probably belongs to protein was shown by hydrolysis of the extracted residue with hydrochloric acid. From 85 to 87 per cent of the nitrogen that was thereby obtained in solution was in the form of amino nitrogen. The failure to obtain in soluble form a larger proportion of the nitrogen of tobacco seed recalls the experience of Jones and Csonka (4) who found that not more than 73 per cent of the nitrogen of feterita and kafir seeds could be brought into solution with alkaline alcohol.

\section{THE GLOBULIN OF THE TOBACCO SEED}

To anticipate slightly it may be said that we have so far demonstrated the presence of only one definite protein in tobacco seed; this is a globulin which, in some respects, resembles edestin from hempseed. Filtered saline extracts of the seed become turbid on heating to about $60^{\circ}$ and it is therefore probable that a small amount of coagulable albumin is present. The best yield of purified globulin obtained as a dry preparation amounted to less than half the probable protein content of the seed, but whether the balance represents exclusively proteins of another type, or in part consists 
of globulin the solubility of which had become altered during the operations of extraction, has not yet been determined.

The globulin may be prepared in several different ways. The following qualitative experiments were designed to show that a similar product is obtained in each case.

\section{PREPARATION OF SALINE EXTRACT}

For the rapid preparation of small quantities of extract $50 \mathrm{gm}$. of fat-free meal were stirred into $500 \mathrm{cc}$. of molar sodium chloride solution at $50^{\circ}$, two $50 \mathrm{~cm}$. square sheets of filter paper were added in small pieces, and the whole was reduced to a pulp. The mass was then squeezed by hand through cheesecloth, the filter paper pulp serving to retain particles of meal, and $325 \mathrm{cc}$. of turbid fluid were secured. The residue, enveloped in the cheesecloth, was pressed at the hydraulic press, an additional $100 \mathrm{cc}$. being thus obtained. The extract was then filtered through a thick pad of filter paper pulp which had previously been washed with molar sodium chloride. The first portion of filtrate was collected separately and returned to the filter, after the extract had run through, to serve as washing fluid. The filtration proceeded rapidly; the filtrate was a perfectly clear, slightly viscous, amber colored fluid that possessed a strong Tyndall effect. The nitrogen in this extract corresponded to 55.2 per cent of the nitrogen of the meal.

A more concentrated extract can be prepared by employing 100 $\mathrm{gm}$. of meal and proceeding in the same way, but the filtration is then much slower.

\section{PREPARATION OF THE GLOBULIN BY DILUTION}

A 500 cc. quantity of clear extract prepared essentially as described and warmed to $50^{\circ}$ was diluted with 10 volumes of water at $50^{\circ}$; the solution remained clear for a short time. It was chilled overnight, the clear top liquid was decanted, and the separated protein was centrifuged off and dissolved in about $200 \mathrm{cc}$. of molar sodium chloride. The solution was clear but was, nevertheless, filtered through pulp previously washed with solvent. The filtrate was diluted as before and allowed to stand for 24 hours. The protein was again dissolved and filtered. A third separation by dilution yielded a product that was instantly soluble in molar sodium chloride to a clear solution. It was washed with water until nearly free from chloride, as evidenced by a tendency to pass into colloidal solution, then with 50 per cent alcohol until free from chloride, and finally with absolute alcohol and ether. The white powder was dried by exposure to the air in a thin layer. The preparation contained 8.00 per cent of moisture and 0.11 per cent of ash. The nitrogen content, calculated ash- and moisture-free, was 18.73 per cent and the sulfur content was 0.97 per cent. 


\section{PREPARATION OF THE GLOBULIN BY DIALYSIS}

A similar 500 cc. quantity of clear extract was placed in a cellophane dialyzing bag together with a little toluene and dialyzed in running water for 2 days. The contents of the bag were rinsed into a centrifuge bottle with water and the separated protein was centrifuged off. It was redissolved in about $200 \mathrm{cc}$. of molar sodium chloride and the solution, though clear, was filtered through pulp. The filtrate was dialyzed a second time, the protein was collected as before, redissolved, filtered, and the solution was dialyzed a third time. The final product was completely soluble in molar sodium chloride and was washed with dilute and with absolute alcohol and finally with ether; it was then dried in the air. It contained 6.59 per cent of water and 0.13 per cent of ash; the nitrogen content was 18.66 per cent and the sulfur content 1.12 per cent, both calculated ash- and moisture-free.

\section{PREPARATION OF THE GLOBULIN BY SALTING OUT}

A third $500 \mathrm{cc}$. quantity of clear extract was treated with a sufficient quantity of dry, powdered ammonium sulfate (132 gm.) to produce a concentration with respect to this salt of approximately 2 molal. The precipitated protein was centrifuged off and was washed with $2.5 \mathrm{M}$ ammonium sulfate. It was then redissolved in $500 \mathrm{cc}$. of molar sodium chloride, in which it was wholly soluble, was filtered through pulp and the protein was precipitated as before. The solution of the protein in molar sodium chloride was this time slightly turbid, due to the presence of a little denatured protein. It was filtered clear and the protein was precipitated a third time. The product was dissolved in $700 \mathrm{cc}$. of molar sodium chloride, was filtered from a trace of denatured protein and was dialyzed into running water until sulfate ion could no longer be detected. The separated protein was centrifuged off, was washed successively with water, 50 per cent alcohol, absolute alcohol, and ether, and dried in the air. It contained 6.46 per cent of moisture and 0.15 per cent of ash. The nitrogen content was 18.54 per cent and the sulfur content 1.00 per cent calculated ash- and moisture-free.

These three methods of preparation yielded products of essentially the same physical and chemical properties. The average nitrogen content was 18.64 per cent and the average sulfur content 1.03 per cent. The preparations were all soluble in molar sodium chloride, but were practically insoluble in water or alcohol ; the customary color tests were all positive and the protein responds in every way to the definition of a globulin. Although none of the above described preparations was well crystallized all contained a few 
crystals; the greater part of each preparation consisted of tiny spherical particles. The preparation of wholly crystalline material is described below and an illustration of the crystals is shown in Figure 56.

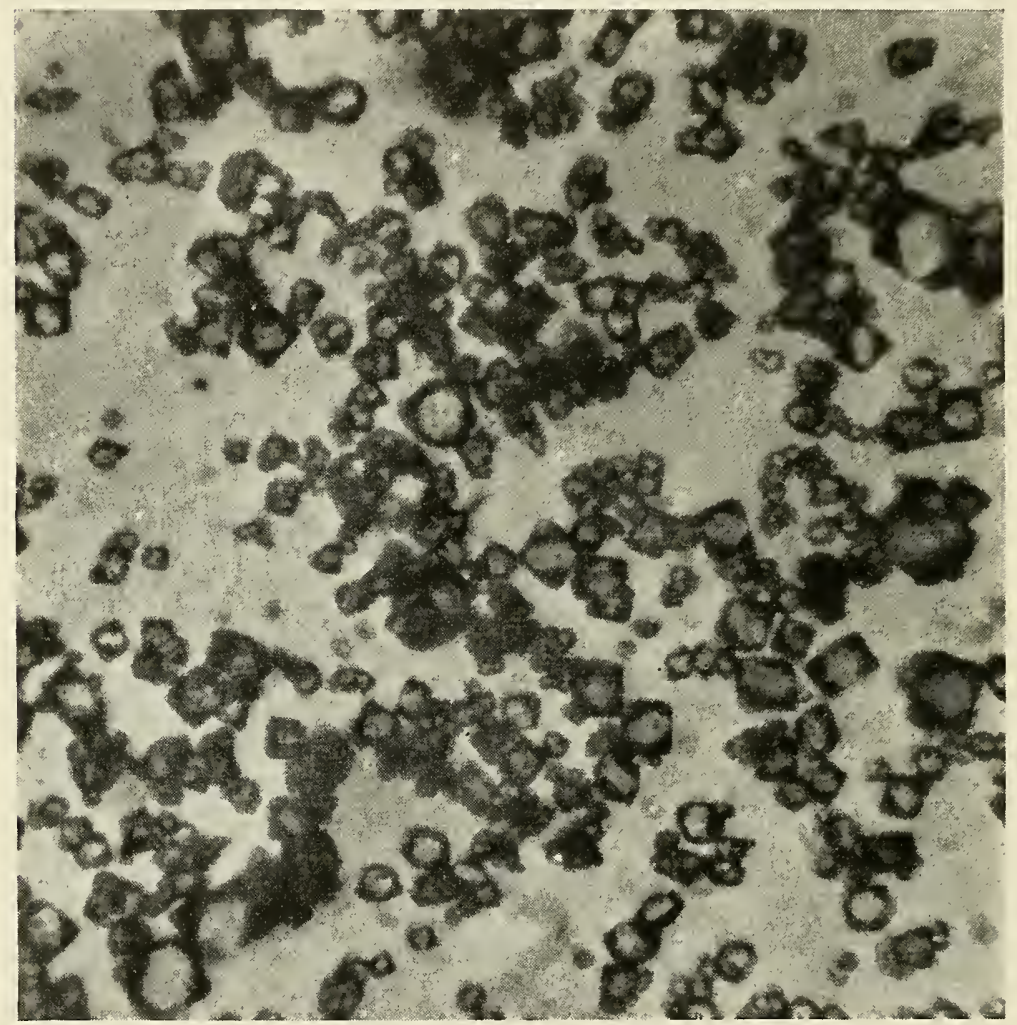

Figure 56. The crystalline globulin of the tobacco seed ( $x$ 500).

PREPARATION OF CRYSTALLINE GLOBULIN

Although it is relatively easy to prepare specimens of tobacco seed globulin that are largely crystalline it was found unusually difficult to secure material that consisted wholly of large, perfectly formed crystals of uniform size. A number of factors appear to influence the outcome of experiments designed to provide such a product but, unfortunately, the exact conditions under which vegetable globulins may best be crystallized have not yet been defined. In the case of the tobacco seed globulin the method of dilution of a warm molar sodium chloride extract of the seed is superior to any 
other for this purpose, and we have found that a number of circumstances have an effect upon the appearance of the final preparation. The saline solution of the protein must be relatively dilute and perfectly clear. It is best to work with ground seed from which the fat has not been removed by ether extraction, and better results appear to be obtained with material that has stood a few days after grinding. The temperature conditions, and rate of cooling are very important, but the range of reaction within which good crystals can be secured is quite broad and, apparently, little attention need be paid to this factor when working with a fresh extract from the seed.

The finest preparations of crystals were secured by stirring 50 gm. of ground seed with $350 \mathrm{cc}$. of molar sodium chloride at $56^{\circ}$ in a warm centrifuge bottle. The pasty mass was then centrifuged; the oil at the surface was sucked off through a capillary tube and the clear extract was decanted from the firmly packed residue through a pad of paper pulp on a Buchner funnel; $275 \mathrm{cc}$. of perfectly clear extract of a reaction at $\mathrm{pH} 5.9$ were secured. This was warmed to $55^{\circ}$, was mixed with 5 volumes of water at $55^{\circ}$, and rapidly filtered through pulp, whereby a sparkling clear filtrate was obtained. A small quantity of toluene was stirred in and the solution, the reaction of which was now at $\mathrm{pH} 6.3$, was allowed to stand at room temperature overnight. The protein then formed a dense deposit at the bottom of the beaker; the supernatant fluid was clear and yielded little or no turbidity on further dilution. Under the microscope the regular octahedral crystals were uniform in size and no amorphous material nor spheroidal particles were visible. The crystals were collected and washed once with 50 per cent alcohol by centrifugation, were then transferred to a filter, and thoroughly washed with absolute alcohol and ether. After being air-dried in a thin layer they were found to have suffered little or no damage.

\section{PREPARATION OF THE GLOBULIN BY EXTRACTION WITH ALKALI}

A $50 \mathrm{gm}$. portion of the fat-free meal was stirred into $500 \mathrm{cc}$. of $0.05 \mathrm{M}$ sodium hydroxide and a sufficient quantity of filter paper clippings was added so as to make a soft mass that could be enveloped in cheesecloth. The extract was expressed by hand and the residue was re-extracted with $500 \mathrm{cc}$. more of alkali; the final residue was pressed at the hydraulic press. The combined extracts, after centrifugation to remove gross particles, were filtered perfectly clear on pulp. Very dilute hydrochloric acid was then slowly adided, during rapid stirring, until the protein had flocculated. The protein was removed and washed and was then dissolved in dilute alkali and reprecipitated twice successively. It was finally dehydrated with alcohol and ether.

Although great care had been taken during the acid precipita- 
tions, the product was extensively denatured, very little of it being soluble in molar sodium chloride. The preparation contained 9.17 per cent of moisture and 0.31 per cent of ash. The nitrogen and sulfur content were 18.28 per cent and 0.83 per cent respectively.

This method of preparation leads to a largely denatured product of lower nitrogen and sulfur, and higher ash content than those obtained by the other methods described.

\section{BASIC AMINO ACIDS OF TOBACCO SEED GLOBULIN}

A quantity of $70.82 \mathrm{gm}$. (corrected) of the globulin prepared by the salting-out method was hydrolyzed by boiling $8 \mathrm{~N}$ sulfuric acid in the customary way and the greater part of the acid was removed as barium sulfate; this was extensively washed. The solution and washings were brought to 2 liters and the basic amino acids were isolated according to the technic described in previous papers from this laboratory (8). The results are shown in Table 4.

$\begin{array}{ccc}\text { Table 4. The Basic Amino Acids of Tobacco Seed Globulin } \\ & \begin{array}{c}\text { From nitrogen } \\ \text { in fraction } \\ \text { per cent }\end{array} & \begin{array}{c}\text { From weight } \\ \text { of salt } \\ \text { per cent }\end{array} \\ \text { Histidine } & 1.28 & 1.09^{1} \\ \text { Arginine } & 16.04 & 13.62^{2} \\ \text { Lysine } & 2.39 & 0.92^{3}\end{array}$

The proportion of arginine given contains the small correction customarily added to allow for the solubility of arginine silver in the alkaline fluid from which it is precipitated. The recrystallized lysine picrate decomposed at $265^{\circ}$ and the proportion given corresponds to the sum of the weight of the recrystallized material and the small quantity in the mother liquor calculated from the solubility of lysine picrate.

Although this globulin resembles those from a number of other oil seeds in its high content of arginine, it yields unusually low proportions of histidine and of lysine. Amandin from the almond approaches it most closely in this respect, but even this protein yields 1.87 per cent of histidine (5). It is, of course, possible that the histidine figures in the old analyses are somewhat high since they are all based upon nitrogen determinations on fractions that almost certainly contained some cystine (9); nevertheless there is little doubt that the tobacco seed globulin yields distinctly less histidine than the other oil seed globulins of which analyses have been reported. There is no apparent possibility of classifying these proteins on the basis of the ratio of the molecular proportions of the basic amino acids, as has been attempted for a series of keratins by Block and Vickery (1).

${ }^{1}$ The histidine diflavianate contained 8.18 per cent sulfur, theory 8.17 per cent.

2The arginine flavianate contained 6.72 per cent sulfur, theory 6.56 per cent.

sThe recrystallized lysine picrate decomposed at $265^{\circ}$. 


\section{THE ISOELECTRIC POINT OF THE GLOBULIN}

Attempts to locate the exact point at which tobacco seed globulin is isoelectric did not lead to conclusive results. When phosphate buffers were employed according to the method of Csonka, Murphy and Jones (2), the point of minimum solubility of a previously dried specimen of the protein was at $\mathrm{pH}$ 5.6. A freshly prepared moist specimen, tested with phthalate buffers, appeared to be least soluble at $\mathrm{pH}$ 5.4. In another series of experiments determinations were made of the nitrogen that passed into solution when specimens of dried or freshly prepared globulin were shaken at room temperature with $M / 20$ phosphate or with $M / 10$ citrate buffers for a definite period of time, usually 3 hours. The solubility did not vary significantly over the range $\mathrm{pH} 5.2$ to 5.5 ; beyond these limits it increased. A few experiments in which approximately $1 \mathrm{gm}$. of fresh moist protein was shaken with $100 \mathrm{cc}$. of citrate buffer solution for 3 hours showed that the effect upon the reaction of the buffer was minimal in the range $\mathrm{pH} 5.3$ to 5.5. Outside of this range appreciable changes in the reaction occurred; for example, the reaction of the buffer at $\mathrm{pH} 5.26$ changed to 5.30 and that of the buffer at $\mathrm{pH} 5.65$ changed to 5.60 .

The available evidence suggests, therefore, that tobacco seed globulin is isoelectric at a point in the vicinity of $\mathrm{pH} 5.4$, the accuracy of the determination probably being not greater than \pm 0.1 units. The isoelectric point of this protein therefore falls within the range observed for many of the seed globulins by Csonka, Murphy and Jones.

\section{THE BEHAVIOR OF THE GLOBULIN TOWARD SALT SOLUTIONS}

A filtered extract prepared from $500 \mathrm{gm}$. of fat-free meal by means of 4500 cc. of molar sodium chloride solution was treated with dry ammonium sulfate, with careful stirring, until the concentration with respect to this salt was 1.5 molal. The flocculent precipitate, which had first appeared at approximately $1 \mathrm{M}$ concentration, settled fairly well, but when a little more of the salt was added to the nearly clear solution a small turbidity developed. The concentration was therefore raised to $2 \mathrm{M}$ and the precipitate (A), after centrifuging, was washed with $2 \mathrm{M}$ ammonium sulfate solution. The addition of more ammonium sulfate to the main solution produced a small turbidity; the concentration was therefore raised to $4.5 \mathrm{M}$ when a small precipitate $(\mathrm{B})$ that settled fairly readily had formed; this was removed. The filtrate, on standing overnight, deposited a little more precipitate (C). Fraction A was dissolved in warm molar sodium chloride, filtered at $60^{\circ}$ through paper pulp from a trace of denatured protein, and the protein was then precipitated by dilution with 5 volumes of water at 
$60^{\circ}$. The protein was reprecipitated twice more by dilution and was finally obtained, after washing in the customary way with alcohol and ether, for the most part in crystalline form, although some spheroidal particles were present. The preparation contained 18.61 per cent of nitrogen, moisture-free, and weighed $55.3 \mathrm{gm}$., or 11 per cent of the fat-free meal taken.

Fraction B was dissolved in $300 \mathrm{cc}$. of water and was again treated with ammonium sulfate. At $2 \mathrm{M}$ concentration a bulky flocculent precipitate had separated which was centrifuged off. On adding more ammonium sulfate the solution became turbid but no flocculation occurred even at $5 \mathrm{M}$. The slimy precipitate was centrifuged as well as possible from the turbid fluid and was placed in a cellophane dialyzer. After complete dialysis of the salts the fluid was still turbid and a very small slimy precipitate had separated. This was instantly soluble in molar sodium chloride but, even on dialysis of this solution, no satisfactory separation could be obtained. The behavior described suggests that the greater part of the protein extracted from tobacco seed meal is a globulin that is thrown out of solution nearly completely at $2 \mathrm{M}$ concentration of ammonium sulfate. In addition there is a small amount of proteinlike material of much less clearly defined solubility.

In another experiment $4600 \mathrm{cc}$. of an extract of $500 \mathrm{gm}$. of meal was diluted to 20 liters with water at $60^{\circ}$ and the moist protein, that separated on standing, was collected and dissolved in $500 \mathrm{cc}$. of molar sodium chloride. Analysis of the solution showed that $530 \mathrm{cc}$. of water were present. Dry ammonium sulfate was added as before; a permanent precipitate first formed when the concentration reached $0.7 \mathrm{M}$ and nearly all the protein had been precipitated at $1.5 \mathrm{M}$; only a little more precipitate separated at $2 \mathrm{M}$ and subsequently only traces were obtained even at $4.3 \mathrm{M}$. The protein, which separates on dilution of a saline extract of tobacco seed, consists almost entirely therefore of globulin that is salted out between the limits of ammonium sulfate concentration 0.7 to $1.5 \mathrm{M}$.

This moist specimen of protein was treated with $300 \mathrm{cc}$. of water, in which it dissolved, and dry sodium chloride was added with stirring until the solution was saturated; a small slimy precipitate separated from the highly colloidal but clear solution. This precipitate, together with the excess sodium chloride, was triturated with $100 \mathrm{cc}$. of saturated sodium chloride solution, whereupon much of it dissolved. The insoluble residue was then separately treated with $100 \mathrm{cc}$. of water; nearly all passed instantly into solution and the small part that remained, apparently denatured protein, was filtered off. This solution was then diluted to $600 \mathrm{cc}$. with water at $60^{\circ}$. On standing, small well-formed crystals of the globulin separated.

The colloidal sodium chloride solution, from which the small 
precipitate had been removed, was treated with magnesium sulfate in an amount necessary to produce a 0.5 molal concentration calculated on the water (approximately $300 \mathrm{cc}$.) originally present. A fine-grained white precipitate separated; this was centrifuged off and a second quantity of magnesium sulfate equal to the first was added. A very small precipitate was thereby produced and the filtrate was free from protein as shown by a negative biuret test.

The precipitate produced by the first portion of magnesium sulfate was dissolved in $400 \mathrm{cc}$. of water at $60^{\circ}$ and the clear solution was diluted to 2 liters. After being chilled the protein separated in small, rather poorly formed octahedral crystals, and in spherules. This preparation, after washing with alcohol, weighed $35.6 \mathrm{gm}$. (8.0 per cent of the meal) and contained 18.41 per cent nitrogen moisture-free.

From these observations it appears that the globulin of the tobacco seed is almost entirely soluble in saturated sodium chloride, very little of it being precipitated under the conditions of the experiment. The whole of the protein is, however, thrown out of such a solution by the addition of a relatively small concentration of magnesium sulfate.

BEHAVIOR OF THE GLOBULIN ON HEATING

A specimen of a molar sodium chloride extract of the seed at $\mathrm{pH} 5.5$, and of 2 per cent concentration with respect to the protein, was carefully heated with continuous stirring in a water bath. At $60^{\circ}$ the solution was faintly turbid and at $77^{\circ}$ definite flocks separated. After centrifugation the clear fluid was heated to $80^{\circ}$ when flocks again separated. The operations of heating very slowly a few degrees and then centrifuging were repeated, flocculations being removed at $84^{\circ}, 85^{\circ}, 89^{\circ}$, $90^{\circ}$, and $94^{\circ}$, and a small residual coagulum after boiling. The reaction had now become more acid ( $\mathrm{pH} 5.3$ ). With the possible exception of the initial turbidity that forms at $60^{\circ}$ there was no definite evidence of the presence of proteins that coagulate at different temperatures; the behavior suggested rather that the globulin is slowly and progressively denatured at temperatures above $77^{\circ}$ in a manner analogous in many ways to the behavior of other seed globulins.

\section{SUMMARY}

The seed of the tobacco plant contains a protein of the globulin type that can readily be prepared in crystalline form by the classical methods. The crystals are regular octahedra occasionally modified into flattened tablets of hexagonal outline. After com- 
plete acid hydrolysis the protein yields 1.09 per cent of histidine, 13.62 per cent of arginine, and 0.92 per cent of lysine; color tests indicate that tryptophane, cystine, and tyrosine are likewise present. The isoelectric point of the globulin lies near $\mathrm{pH}$ 5.4. It is almost completely salted out of a relatively concentrated solution by ammonium sulfate between the limits 0.7 to $1.5 \mathrm{M}$, but is soluble in saturated sodium chloride solution. On heating its solution in molar sodium chloride at $\mathrm{pH} 5.5$ it is slowly and progressively denatured at temperatures higher than $77^{\circ}$.

\section{BIBLIOGRAPHY}

1. Block, R. J., and Vickery, H. B., Jour. Biol. Chem., 93 : 113. 1931.

2. Csonka, F. A., Murphy, J. C., and Jones, D. B., Jour. Amer. Chem. Soc., 48: 763. 1926.

3. Ilyin, G., U. S. S. R. State Inst. Tobacco Investigations, Bul. 57 (in Russian). 1929.

4. Jonks, D. B., and CsonkA, F. A., Jour. Biol. Chem., 88: 305. 1930.

5. Osborne, T. B., Leavenworth, C. S., and Brautlecht, C. A., Amer. Jour. Physiol., 23 : 180. 1908.

6. Paris, G., Bol. tec. (R. ist. sper. coltiv. tabacchi, Scafati), 17 : No. 1. 101. 1920.

7. Preissecker, K., and Brezina, H., Fachl. Mitt. österr. Tabakregie, No. 4. 1917.

8. Vickery, H. B., and Block, R. J., Jour. Biol. Chem., 86: 107. 1930.

9. Vickery, H. B., and Leavenworth, C. S., Jour. Biol. Chem., 83 : 523. 1929.

10. Vickery, H. B., and Pucher, G. W., Conn. Agr. Expt. Sta., Bul. 311 : 234. 1930. 


\section{PART III}

\section{SOME NITROGENOUS COMPONENTS OF THE HOT WATER EXTRACT \\ OF FAT-FREE TOBACCO SEED MEAL}

\section{Hubert Bradford Vickery}

The literature on the composition of water extracts made from plant seeds is surprisingly meager. Most investigations of seeds have dealt exclusively with the detection or determination of a single type of substance, such as allantoin or an alkaloid, but no comprehensive chemical investigation of the water extract of seeds has come to our attention. The desirability of such investigations is manifest; seeds form a large part of the nutriment of animals and, although the greater part of their food value arises from the carbohydrate, protein, fat, and inorganic salts they contain, there is little doubt that substances present in minute amounts, such as the vitamins, are also of great importance in animal nutrition. The significance of chemical studies of seeds far transcends this, however. The seed provides the store of food upon which the growth of the embryo of the plant depends until its organs of assimilation are developed-every necessary constituent of the food, save water and oxygen, is therefore actually or potentially present, and the study of the chemical composition of seeds is really, therefore, the study of the composition of the nutriment furnished to the developing embryo.

The present investigation had its origin in the observation (4) that tobacco seeds contain no nicotine, but, after being allowed to germinate for 9 to 11 days, quite appreciable quantities of this alkaloid develop in the seedlings. The normal metabolism of the tobacco plant therefore produces nicotine even at the earliest stages and, furthermore, a chemical mechanism is present whereby nicotine can be synthesized from non-alkaloidal precursors stored within the seed. It seemed of importance to attempt to identify these precursors. Although the preliminary search was unsuccessful the experience gained has indicated how the problem can be again attacked with hope for a more successful outcome.

\section{PREPARATION OF HOT IVATER EXTRACT}

Seed obtained from shade-grown tobacco of the 1929 crop was ground in a poppy seed mill. The pasty mass was weighed and extracted with light gasoline twice successively; the material was then washed with a liberal quantity of ether and spread out in a thin layer to dry. After all the ether had evaporated the meal 
was again passed through the mill. Treated in this way $2955 \mathrm{gm}$. of freshly ground tobacco seed yielded $1738 \mathrm{gm}$. of air-dry meal. The loss of $1217 \mathrm{gm}$. or 41.2 per cent represents the oil removed by the solvents. The air-dry meal contained 7.01 per cent of moisture; after being completely dried it contained 7.11 per cent of nitrogen.

The meal was slowly introduced into about 13 liters of boiling distilled water and was boiled for 15 minutes. Enough dilute sulfuric acid to bring the reaction to $\mathrm{pH} 4$ was then added and, after being allowed to mascerate for several hours, the insoluble residue was filtered off. This was boiled as before with 15 liters of water to which enough sulfuric acid had been added to bring the reaction to $\mathrm{pH} \mathrm{4,} \mathrm{and} \mathrm{the} \mathrm{operation} \mathrm{was} \mathrm{repeated} \mathrm{a} \mathrm{third} \mathrm{time.}$ The final residue was enveloped in filter cloth and pressed dry at the hydraulic press, the cakes were then stirred up with water and were pressed a second time.

The acidity of the extracts was reduced to $\mathrm{pH} 5$ to 6 by the addition of barium hydroxide and the solutions were evaporated, at first in open dishes and then in vacuum stills, to a volume of about 10 liters; the solution was then filtered and further concentrated to 2 liters. Alcohol to make a total volume of 5 liters was added and the precipitate, which settled after the solution had been chilled overnight, was removed. This was thoroughly washed with alcohol and dried. It weighed $232 \mathrm{gm}$., or 13.6 per cent of the fat-free meal, and contained 39.75 per cent of ash and 4.11

Table 5. Composition of the Hot Water Extract Prepared FROM TOBacCo SEEd MEAL

Whole seed

Fat-extracted meal

Nitrogen in fat-extracted meal

Ash

Alcohol precipitate

Nitrogen in alcohol precipitate

Ash

Nitrogen in water extract

Ammonia nitrogen in water extract

Amide

Amino

Organic solids

Ash

$\begin{array}{ccc}\begin{array}{c}\text { Extract } 1 \\ \text { gm. }\end{array} & \begin{array}{c}\text { Extract } 2 \\ \text { gm. } \\ 2955\end{array} & \begin{array}{c}\text { Total } \\ \text { gm. } \\ 140\end{array} \\ 1710 & 1284 & 295 \\ 121.6 & 84.74 & 2094 \\ 101.7 & 76.4 & 178.1 \\ 232.1 & 158.2 & 380.3 \\ 9.56 & 6.38 & 15.94 \\ 92.26 & 63.72 & 155.9 \\ 6.77 & 6.50 & 13.27 \\ 0.321 & 0.294 & 0.615 \\ 0.743 & 0.576 & 1.319 \\ 1.38 & 0.86 & 2.24 \\ 115.9 & 111.9 & 227.8 \\ 12.6 & 13.1 & 25.7\end{array}$

per cent of nitrogen. If the nitrogen is assumed to be in the form of coagulated protein the product must have contained at least $80 \mathrm{gm}$., or 33 per cent, of non-protein organic substances, some of which probably consisted of substances allied to the pectins.

The alcoholic solution was concentrated to a sirup, was diluted and filtered from a trace of insoluble material, and was then made 
to a definite volume for analysis. A second extract from $1284 \mathrm{gm}$. of fat-free seed was similarly prepared and analyzed and the two were united after the removal of the barium hydroxide-alcohol precipitates described in the following section.

In Table 5 are given the analytical data on these two extracts together with sums of the separate items. The combined solutions were then examined in detail according to the methods of fractionation in current use in this laboratory.

\section{THE BARIUM HYDROXIDE-ALCOHOL PRECIPITATION}

The procedure followed in removing the substances that are precipitated by barium hydroxide from an alcoholic ( 50 per cent) solution was substantially that already described in detail on page 173 of Bulletin 323 (5) of this Station; this Bulletin likewise contains the data obtained from the detailed analysis of the precipitate.

\section{THE NEUBERG REAGENT PRECIPITATION}

The combined filtrates from the barium hydroxide-alcohol precipitations were treated with mercuric acetate, sodium carbonate and alcohol according to the technique described by Neuberg and Kerb (1). This procedure has been found to effect an important concentration of the nitrogenous substances and a purification of these from the non-nitrogenous substances present in the extract. The precipitate produced was decomposed by hydrogen sulfide and was found to contain $8.27 \mathrm{gm}$. of nitrogen, or 62.3 per cent of the water soluble nitrogen of the seed, distributed as is shown in Table 6.

Table 6. The Composition of the Neuberg Precipitate

$\begin{array}{ll} & \text { gm. } \\ \text { Total nitrogen } & 8.27 \\ \text { Ammonia “" } & 0.76 \\ \text { Amide “ } & 0.578 \\ \text { Amino " } & 1.86 \\ \text { Peptide “ } & 1.81 \\ \text { Organic solids } & 76.88 \\ \text { Ash } & 6.01\end{array}$

This fraction contains those substances that possess an amino group in the a position to a carboxyl group, that is, the amino acids; peptides of these together with basic substances, such as the purines and pyrimidines; and a variety of substances the nature of which is still unknown are also present. The separation of the individual components of such a mixture has provided an analytical problem that is still far from solution. At the present time it is 
possible only to divide the mixture into subfractions that contain substances of essentially similar types, and to isolate a few of the components the properties of which are sufficiently well known to permit of this. For the rest it is necessary to depend upon indirect methods of analysis where these can be supplied.

\section{SUBFRACTIONATION BY MEANS OF SILVER COMPOUNDS}

Previous experience in this laboratory has shown that fairly definite subfractions of the mixture usually present in mercuric acetate precipitates can be obtained by precipitation of silver compounds between selected $\mathrm{pH}$ limits. This procedure has found wide application in dealing with the relatively much simpler mixtures of substances in protein hydrolysates, and the particular $\mathrm{pH}$ limits chosen in the present work are those that have been found most useful in the analysis of proteins; such a selection is, of course, purely arbitrary in the present case.

The actual technique employed was substantially that described by Vickery and Leavenworth (3). A preliminary precipitation of the silver compounds was made at strongly alkaline reaction; the material so obtained was then fractionated into silver compounds insoluble at $\mathrm{pH} \mathrm{4,pH} \mathrm{7,} \mathrm{and} \mathrm{pH} 12$. These three fractions are designated the Purine, Histidine, and Arginine fractions respectively, and the combined filtrates form the Lysine fraction.

\section{THE PURINE FRACTION}

The purine fraction prepared by precipitation of the silver compounds at $\mathrm{pH} 4$ contains, in addition to true purines, other substances that form acid insoluble silver salts. To separate the true purines from these the solution was made alkaline with ammonia and an excess of silver oxide was added; the precipitate produced was then examined for purines. Adenine and guanine were found in the amounts shown in Table 7.

\section{Table 7. The Purine Fraction}

Total nitrogen of the fraction

Nitrogen of adenine

"guanine

" filtrate from ammoniacal silver precipitate

$$
\begin{aligned}
& \text { gm. } \\
& 2.08 \\
& 0.254 \\
& 0.024 \\
& 1.452
\end{aligned}
$$

It is clear that the true purines form only a small part of the nitrogenous substances of this important fraction. Attempts to isolate definite substances from the non-purine part were unsuccessful; a small amount of organic acid was present, and positive color tests were obtained with diazobenzenesulfonic acid and with Folin's phosphotungstic acid reagent; substances that 
contain nitrogenous ring structures, perhaps of the imidazole or pyrimidine type, therefore probably occurred in it. Attempts at isolation of definite compounds with such reagents as flavianic acid or mercuric sulfate showed that basic substances were present, but no crystalline products could be brought to separate.

\section{THE HISTIDINE FRACTION}

This fraction contained only $0.593 \mathrm{gm}$. of nitrogen. It gave positive color tests for imidazole compounds, but treatment with mercuric sulfate in the manner customarily employed for the isolation of histidine precipitated less than one-tenth of the nitrogen of the fraction and no histidine diflavianate could be obtained from the precipitate. The filtrate from the mercuric sulfate precipitate yielded allantoin, by direct crystallization, in an amount equivalent to $0.102 \mathrm{gm}$. of nitrogen, or 17.3 per cent of the nitrogen of the fraction. The product was identified by its decomposition point of $232^{\circ}$, which was unchanged by admixture with authentic allantoin. This substance has previously been reported as a constituent of tobacco seed by Scurti and Perciabosco (2).

The filtrate from the allantoin contained an appreciable amount of peptides of amino acids, inasmuch as its amino nitrogen was increased from 19.1 to 44.7 per cent of the total nitrogen by severe hydrolysis.

\section{THE ARGININE FRACTION}

This fraction contained $1.12 \mathrm{gm}$. of nitrogen or 13.5 per cent of the nitrogen of the Neuberg reagent precipitate. A small amount of arginine (flavianate, S 6.60, theory 6.56 per cent) was isolated by treatment of this solution with flavianic acid. An oily flavianate which appeared to contain a peptide of arginine likewise separated. After complete hydrolysis the amino nitrogen in this material was increased from 27.3 to 56.7 per cent, and subsequent treatment with flavianic acid afforded pure arginine flavianate ( $S 6.56$ per cent) in an amount equivalent to the non-amino nitrogen of the solution after hydrolysis.

After removal of the substances precipitated by flavianic acid, and also of the reagents, the solution was subjected to direct crystallization whereby allantoin of decomposition point $231^{\circ}$ separated (C 30.30, H 3.93, N 35.14; theory C 30.33, H 3.83, N 35.49 per cent) in an amount equivalent to $0.137 \mathrm{gm}$. of nitrogen. The mother liquor was hydrolyzed with acid whereby the amino nitrogen was increased from 17.1 to 43.1 per cent of the total nitrogen; peptides of amino acids were therefore present.

The arginine fraction contained $0.219 \mathrm{gm}$. of arginine nitrogen, $0.137 \mathrm{gm}$. of allantoin nitrogen, and $0.194 \mathrm{gm}$. of peptide nitrogen, making in all 49 per cent of the total nitrogen in assigned forms. 


\section{THE LYSINE FRACTION}

The filtrates from the silver precipitates at alkaline reaction were combined and freed from barium and silver. The basic substances were then precipitated by phosphotungstic acid and the precipitate was treated, in the usual way, with acetone. A part of it failed to dissolve; this was therefore removed and decomposed by treatment in aqueous suspension with barium hydroxide. The two fractions were subsequently dealt with separately.

The results of indirect analysis of these fractions can be most concisely presented in tabular form (Table 8). The losses of nitrogen in the operations of regenerating the basic substances from the phosphotungstic acid precipitates were severe; $1.62 \mathrm{gm}$., or 36 per cent of the total nitrogen disappeared, probably for the most part adsorbed on the precipitates, although a part of this may have been present as ammonia which volatilized from the alkaline solutions. Similar severe losses have been encountered in dealing with phosphotungstic acid precipitates obtained from other plant extracts.

The solution derived from the acetone soluble phosphotungstates was treated in the usual way with picric acid but no crystalline material could be obtained from it. It was therefore subjected to severe hydrolysis, the basic substances were precipitated by phosphotungstic acid, and an attempt was again made to isolate lysine as the picrate. Even after seeding with pure lysine picrate nothing could be brought to crystallization and it was evident that this fraction contained little, if any, lysine.

Table 8. The Lysine Fraction

Nitrogen $4.48 \mathrm{gm}$.

$\begin{array}{lccc} & \begin{array}{c}\text { Acetone } \\ \text { soluble } \\ \text { phospho- } \\ \text { tungstates }\end{array} & \begin{array}{c}\text { Acetone } \\ \text { insoluble } \\ \text { phospho. } \\ \text { tungstates }\end{array} & \begin{array}{c}\text { Filtrate from } \\ \text { phosphotungstic } \\ \text { acid } \\ \text { (Mono amino } \\ \text { acid fraction) }\end{array} \\ \text { Total nitrogen } & \text { gm. } & \text { gm. } & \text { gm. } \\ \text { Amino "“ } & 0.548 & 0.543 & 1.771 \\ \text { Peptide " } & 0.122 & 0.055 & 0.649 \\ & 0.196 & 0.094 & 0.253\end{array}$

THE MONO AMINO ACID FRACTION

The filtrate from the phosphotungstic acid precipitate was freed from reagents and evaporated to a sirup. In order to see if any asparagine had survived the previous operations this sirup was seeded with a small fragment of asparagine. No crystallization occurred even after treatment with alcohol, and it was therefore inferred that asparagine could have been present at most in only very small amounts. 
The fraction was next subjected to severe hydrolysis and an attempt was made to separate the dicarboxylic acids by precipitation with barium hydroxide and alcohol. The precipitate contained 15 per cent of the total nitrogen of the fraction, but yielded no aspartic acid when treated in the customary way with copper hydroxide. It seems evident, therefore, that asparagine made up no significant part of the original amide nitrogen of the tobacco seed extract.

The filtrate from the dicarboxylates, after being freed from reagents, was evaporated to a sirup. A mixture of amino acids separated but the total quantity was too small to permit isolation of individual substances.

\section{THE FILTRATE FROM THE NEUBERG REAGENT PRECIPITATE}

After removal of reagents the basic substances in this filtrate were precipitated by phosphotungstic acid and the solution obtained by decomposition of the phosphotungstates was investigated for quaternary bases.

Nicotinic acid could not be detected in this solution. The chief component, choline, was isolated for the most part by direct crystallization of the picrate. Recourse was then had to Stanêk's periodide procedure to separate the rest of the choline from the other basic substance present; this turned out to be betaine. The choline picrate was identified by its melting point $\left(248^{\circ}\right)$ and by analysis for nitrogen (16.8 per cent; theory 16.87 per cent). The betaine picrate melted at 182 to $183^{\circ}$ and contained C 38.38 , H 4.11, N 16.19 per cent ; theory C 38.15, H 4.04, N 16.18 per cent.

The quantities of these two bases that were isolated from this fraction are shown in Table 9; together they account for 86.5 per cent of the basic nitrogen of the filtrate from the Neuberg reagent precipitate.

$\begin{array}{cc}\text { Table 9. Choline and Betaine Isolated as Picrates from the } \\ \text { Betaine Fraction } & \text { gm. } \\ \text { Total nitrogen of the fraction } & 0.528 \\ \text { Nitrogen of choline from main crystallization of picrate } & 0.331 \\ \text { " " " betaine " periodide precipitate } & 0.059 \\ \text { " " "mother liquor of periodide } & 0.067 \\ \text { Total nitrogen isolated } & 0.016 \\ \end{array}$

\section{DISCUSSION}

The chief results of the fractionation of this extract of tobacco seed are shown in Table 10. It is clear that a large part of the nitrogen belongs to substances that are essentially basic in their behavior towards the customary precipitants. A disappointingly 
small part of the total nitrogen was isolated as definite crystalline substances, and the evidence points unmistakably to the presence of large proportions of nitrogenous compounds of wholly unknown nature. It is unlikely that these belong to types strange to organic chemistry; obviously new methods of attack must be devised in order to secure some idea of what this unknown material may be.

Table 10. Distribution of Nitrogen in Fractions

\begin{tabular}{|c|c|c|c|c|}
\hline \multirow{2}{*}{\multicolumn{2}{|c|}{ Total nitrogen of extract $\mathrm{gm}}}$. & per cent & \multirow{2}{*}{$\begin{array}{c}\text { gm. } \\
13.27 \\
1.625\end{array}$} & $\begin{array}{l}\text { per cent } \\
100 .\end{array}$ \\
\hline \multicolumn{2}{|c|}{ Barium hydroxide-alcohol precipitate } & & & 12.2 \\
\hline Neuberg reagent precipitate & 8.27 & 100. & 8.27 & 62.3 \\
\hline Purine fraction & 2.08 & 25.2 & & \\
\hline Histidine " & 0.593 & 7.2 & & \\
\hline Arginine " & 1.12 & 13.5 & & \\
\hline Lysine “ & 1.19 & 14.4 & & \\
\hline Mono-amino fraction & 1.77 & 21.4 & & \\
\hline \multicolumn{5}{|l|}{ Filtrate from Netuberg reagent } \\
\hline precipitate & 1.28 & 100 & 1.28 & 9.67 \\
\hline Choline fraction & 0.528 & 41.2 & 0.528 & 3.98 \\
\hline
\end{tabular}

The present methods gave satisfactory results only in the detailed analysis of the choline fraction. This fraction is much simpler in composition than the others; by far the greater part of the nitrogen belonged to the two substances choline and betaine. Although traces of other quaternary bases may have been present, at the outside these could account for considerably less than 1 per cent of the nitrogen of the original tobacco seed extract.

The substances isolated are shown in Table 11. In all they account for 2.55 per cent of the organic solicts and 8.98 per cent of the nitrogen of the seed extract.

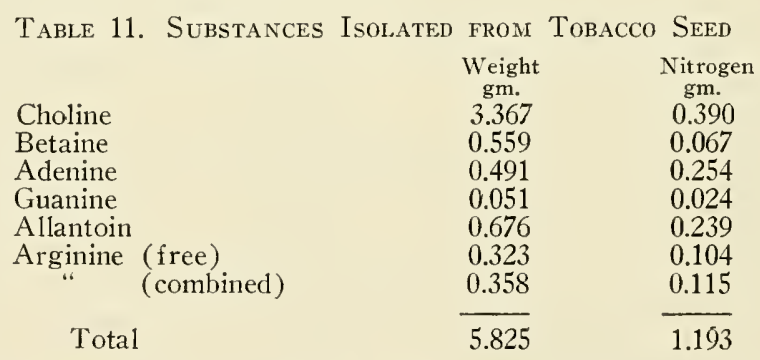

A somewhat more encouraging result is shown in Table 12 which gives the distribution of the nitrogen in known forms; about 60 per cent of the nitrogen is accounted for. The estimation of the peptide nitrogen is derived from independent data secured from an extract of the same tobacco seed. The quantity of amino nitrogen reported has been corrected for the small quantity of amino nitrogen contributed by the isolated substances. 
Table 12. Distribution of Nitrogen in Known Forms

Total nitrogen
Ammonia "
Amide " $\quad$ (corrected)
Amino " $\quad$ (estimated)
Peptide
Isolated substances
Other nitrogen

$\begin{array}{rc}\text { gm. } & \text { per cent } \\ 13.27 & 100 . \\ 0.62 & 4.67 \\ 1.32 & 9.93 \\ 2.20 & 16.6 \\ 2.38 & 17.9 \\ 1.19 & 8.98 \\ 5.29 & 39.8\end{array}$

\section{SUMMARY}

A hot water extract prepared from fat-free tobacco seed has been examined with respect to the forms of nitrogen it contains. Approximately 60 per cent of this nitrogen was accounted for in terms of well-recognized nitrogenous groupings and nearly 9 per cent was isolated in the form of pure crystalline substances. It seems certain that a large part of the unknown forms of nitrogen is contained in basic substances many of which contain nitrogen in cyclic structures. No evidence was secured of the origin of the nicotine that is produced very soon after sprouting of this seed occurs.

\section{BIBLIOGRAPHY}

1. Neuberg, C., and KerB, J., Biochem. Ztschr., 40: 498. 1912.

2. Scurti, F., and Perciabosco, F., Gaz. chim. ital., 36: II, 626. 1906.

3. Vickery, H. B., and Leavenworth, C. S., Jour. Biol. Chem., 76: 707. 1928.

4. Vickery, H. B., and Pucher, G. W., Conn. Agr. Expt. Sta., Bul. 311 : 234. 1930.

5. Vickery, H. B., and Pucher, G. Ir., Comn. Agr. Expt. Sta., Bul. 323. 1931. 


\section{A MICROCHEMICAL STUDI OF THE SEED OF NICOTIANA TABACUM}

\section{Florence A. MCCormick ${ }^{1}$}

The interest of the Department of Biochemistry in the chemistry of tobacco seed has given rise to a number of questions concerning the structure of the seed and the identification and location in it of various substances, especially protein and fat. It was the desire to have at hand a concrete picture of such facts that led to the request for the present brief study.

Splendore (5) in his paper on the genus Nicotiana has photographs of seeds of many varieties of $N$. Tabacum and he gives comparative weights and measurements of them. He does not consider the interior of the seed. Behrens (1) gives a short description of the markings of the testa and of the embryo and endosperm. Jensen (2) adds more details concerning the size and shape of the seed and the markings of the testa. Behrens and Jensen give the weight of the individual seed as about $0.08 \mathrm{mg}$. and Splendore's weights are slightly less.

In the present investigation Connecticut Havana tobacco seed was studied. The mature seeds are a cinnamon brown. There is considerable variation in shape, but they are commonly ellipticalovate (Plate 18, Fig. 6) with the longer diameter in 10 seeds averaging $714 \mu$ and the shorter $571 \mu$. The seeds are anatropous with the short, often curved, funiculus remaining attached at the narrow end. Radiating from the base of the funiculus and extending over the entire seed is a network of thickened wavy cell walls of the testa which, under low magnification, give a roughened appearance (Plate 18, Fig. 1,2). The raphe, usually represented by a ridge in anatropous seeds, is not externally apparent in this seed.

Seeds were killed for sectioning in a saturated alcoholic solution of picric acid, in Benda's solution, in Fleming's strong solution, and in acetic acid-alcohol. For the microchemical tests, thoroughly dried seeds, not previously treated with any killing agent, were kept in melted paraffin in an electric oven at a temperature of $52^{\circ} \mathrm{C}$ for 24 hours before embedding, and these were then sectioned with a rotary microtome, a section of a seed so treated being represented in Plate 18 , Figure 6 . Such seeds, left in the continuously melted paraffin from October 28, 1931, to

\footnotetext{
${ }^{1}$ Of the Department of Botany.
} 
June 18, 1932, germinated when put into a moist chamber. Sections of the untreated seeds were cut $5 \mu$, to $25 \mu$, 20 $\mu$ being the most favorable for general study. Thinner sections of seeds killed in the reagents were used for comparison.

Testa. The epidermis of the ovule undergoes a marked change during the development of the embryo. The outer walls remain thin and, in the mature seed, usually only fragments of them are left. The inner and lateral walls, however, become greatly thickened and to the latter ones are due the conspicuous markings of the testa mentioned above. This increase in thickness of the inner and lateral walls can be seen by comparing Figures 3 and 4 in Plate 18 with any sections of the mature seed, particularly Figure 6. In Figure 3 there is represented an ovule containing a small embryo. The epidermal cells are large with the inner and lateral walls beginning to thicken. Figure 4 shows a decided thickening of the same walls, while sections of the mature seeds show remnants of the outer walls and the greatly thickened inner and lateral walls. The crushed empty cells beneath the epidermis appear almost homogenous in the photographs of the mature seed (Figs. 7 and 8).

Embryo and endosperm. The embryo (Fig. 6, em) is usually somewhat kidney-shaped with the concave side lying toward the raphe. It is a thickened and elongated body with the large cotyledons (Fig. 6, c) extending about one-third its length and with no apparent plumule. It is about $613 \mu$ long and $250 \mu$ broad and comprises about one-fourth the volume of the seed. Endosperm (Fig. 6, end) completely surrounds the embryo, but there is relatively little of it over the narrowed tip of the radicle (Fig. 6 , rad) and the rounded ends of the cotyledons. The cells of the embryo are small and are filled with granules varying in size, but on the whole considerably smaller than those in the endosperm. The region of the raphe (Fig. 7, r) is marked by a single layer of outermost cells. These cells are somewhat smaller than the contiguous cells of the endosperm, are more nearly rectangular in shape, and contain granules which are more uniform in shape and smaller even than those in the embryo. Figures 7 and 8 are enlarged views of parts of the endosperm, Figure 7 showing a part of the region of the raphe $(r)$, of the endosperm (end) and of the embryo (em), and Figure $\&$ showing a part of the side opposite the raphe.

\section{MICROCHEMICAL TESTS}

Microchemical tests were made for starch, protein, and fat. 


\section{STARCH}

The mature seed contains no starch. In the ovule, while the embryo is still immature, there is starch in the nucellar tisste (Figures 3 and 4, s), but this disappears before the embryo is fully developed. Both figures are photographs of a section of an ovule stained with iodine alone, thus differentiating the starch grains (s) which are limited, at this stage to the periphery. Seeds, germinated on moist filter paper show, when the seedlings are about $1 \mathrm{r} / 4 \mathrm{~mm}$. to $2 \mathrm{~mm}$. long and before the cotyledons have emerged, a trace of starch about in the middle of the hypocotyl (Figure 5, s). The section from which this photograph was made, was also stained in iodine alone and was of a seedling the cotyledons of which were similar to those shown in Plate 19, Figure 16.

Thus we see that there is starch in the ovule, none in the mature seed and that it early reappears in the hypocotyl of the young seedling.

\section{PROTEIN}

For the most part Klein's Prakticum der Histochemie (3) was followed in the study of the distribution of protein. The Enzyklopadie der mikroskopischen Technik (4) and Pflanzenmicrochemie by Tunmann (6) were also consulted.

As stated above, sections of seeds embedded in paraffin but not previously treated with any killing agent, were used in the microchemical tests. Sections were tested both with and without the removal of paraffin, these showing, however, no appreciable difference in the results. The tests used indicate that the granules which fill the cells of the mature seed are protein, but the granules in the cells of the embryo, the endosperm and the region of the raphe differ in their reactions to the microchemical tests. The relatively large granules of the endosperm stain more deeply and, on prolonged treatment with the reagent, show even a different color from that of the smaller granules of the embryo and the still smaller granules in the cells of the raphe. The granules in the embryo and raphe stain more nearly alike, but those of the raphe, while staining the same color, retain a somewhat lighter shade. Plate 19, Figure 14 represents a transverse section of a seed showing the difference in staining of these three regions. The embryo (Fig. 14, em) is surrounded by the darker endosperm (Fig. 14, end) and a part of the region of the raphe is shown at $r$. The section from which the photograph was made was stained in gentian violet alone, but shows typical differences in the staining of the three regions. A similar differentiation is exhibited by sections stained with the biuret reagents. The difference in size of the granules can scarcely account for this distinction in staining. 
The difference in size of the granules and the difference in the reaction to microchemical tests suggest that there may also be a chemical difference.

Biuret test. The protein of the endosperm, when treated with the biuret reagents, becomes a deep lavender and the embryo a gray with a tinge of lavender. With prolonged staining the endosperm becomes deeper in color and the lavender tone in the embryo disappears, leaving it a light grayish brown. The raphe is lighter than the embryo and has no lavender tone. During germination the disintegration can be seen progressing from the micropylar end of the seed toward the chalazal end (Figs. 12, 13, and 14) and, at this stage, there is an increased difference in staining between the embryo and endosperm. indicating that in the growing seedling the protein in the embryo is used sooner than that in the endosperm. The embryo gives a very slight protein reaction while the endosperm still retains granules that stain a deep lavender.

Willon's reagent. With this reagent the endosperm and embryo become an orange yellow, the endosperm containing more red and the raphe staining lighter than the embryo, so that three intensities of color may be seen in the section.

Xantho-protcin test. When nitric acid alone is put on sections of tobacco seed the testa immediately becomes a deep yellow developing into an orange. The embryo and endosperm more slowly become a light yellow. When ammonia is added the color is intensified, the endosperm being slightly darker than the embryo. When 50 per cent caustic soda, or 50 per cent caustic potash is used instead of ammonia both regions become orange, the endosperm staining more deeply than the embryo.

Picric acid. An aqueous solution of picric acid stains the entire section yellow. However, the endosperm is a clear lemon yellow while the embryo and raphe are a grayish yellow deeper in tone than the endosperm.

Vanillin test. Both embryo and endosperm stain a distinct violet. The endosperm stains a much deeper shade than the embryo.

\section{FAT}

The seeds killed in Benda's solution as well as in Fleming's strong solution show in sections a surprisingly small area blackened with the osmic acid. The largest amount of fat reaction is at the micropylar end and in the outermost layer of endosperm, which becomes an intense black. The rest of the endosperm and the embryo stained either a light brown or not at all. The result was the same even though the racuum pump was used and the seeds were left in the killing agent 48 hours with a change to fresh killing solution after 24 hours. This is evidently due to the lack 
of penetration of the osmic acid in these solutions and not to a lack of fat in the slightly or uncolored areas, for sections made from the material killed in these osmic acid solutions, when put into water containing a few drops of 2 per cent osmic acid alone, stained a deep black over the entire section. Sections of seeds, embedded in paraffin, but not killed, were treated with osmic acid alone; these also became uniformly black in endosperm and embryo. Sudan III and Oil Red $O$ were likewise used and indicated fat both in endosperm and embryo.

Figure 17 is a photograph of a cross section of a seed that had been embedded in paraffin. The tissues had not been killed before embedding and the paraffin had not been removed when the photograph was taken nor had any staining reagent been added. To prevent loss of fat the slide was left on the stage of the microscope and a drop of osmic acid was then put on this section. To avoid smearing no cover glass was added. Figure 18 is a photograph of this section after being treated with osmic acid. The intense blackening demonstrates the presence of fat both in the endosperm and the embryo.

\section{RESULTS}

The seeds of Nicotiana Tabacum contain no starch. There is starch in the ovule and it develops very early in the hypocotyi of the young seedling.

Both endosperm and embryo contain an abundance of protein. The difference in size of the protein granules in these two parts and the difference in reaction to the tests suggest that there may be a chemical difference. The amount of protein in the raphe is obviously small, but there is an indication that it is also unlike that of the endosperm and more nearly resembles that of the embryo. The granules are smaller and they stain more lightly than those of the embryo, which may imply that they are also chemically distinct from those in the embryo and endosperm.

There is present both in endosperm and embryo a large amount of fat, which only appears in globules after the microchemical tests have been applied. No attempt has been made to estimate the relative amounts in the two regions.

\section{BIBLIOGRAPHY}

1. Behrens, J., Landw. Vers. Sta., 41 : 191. 1892.

2. Jensen, H., Proefsta. Vorstenland. Tabak (Dutch East Indies), Meded., 28. 1917.

3. KLeIN, G., Prakticum der Histochemie. IVien and Berlin 1929.

4. Krause, R., Enzyklopadie der mikroskopischen Technik. (Berlin) 1926.

5. Splendore, A., Bol. tec. (R. ist. sper. coltiv. tabacchi. Scafati), 5: No. 4-5. 1906 .

6. Tumanan, O., Pflanzenmikrochemie. (Berlin) 1913. 
PLATE 18

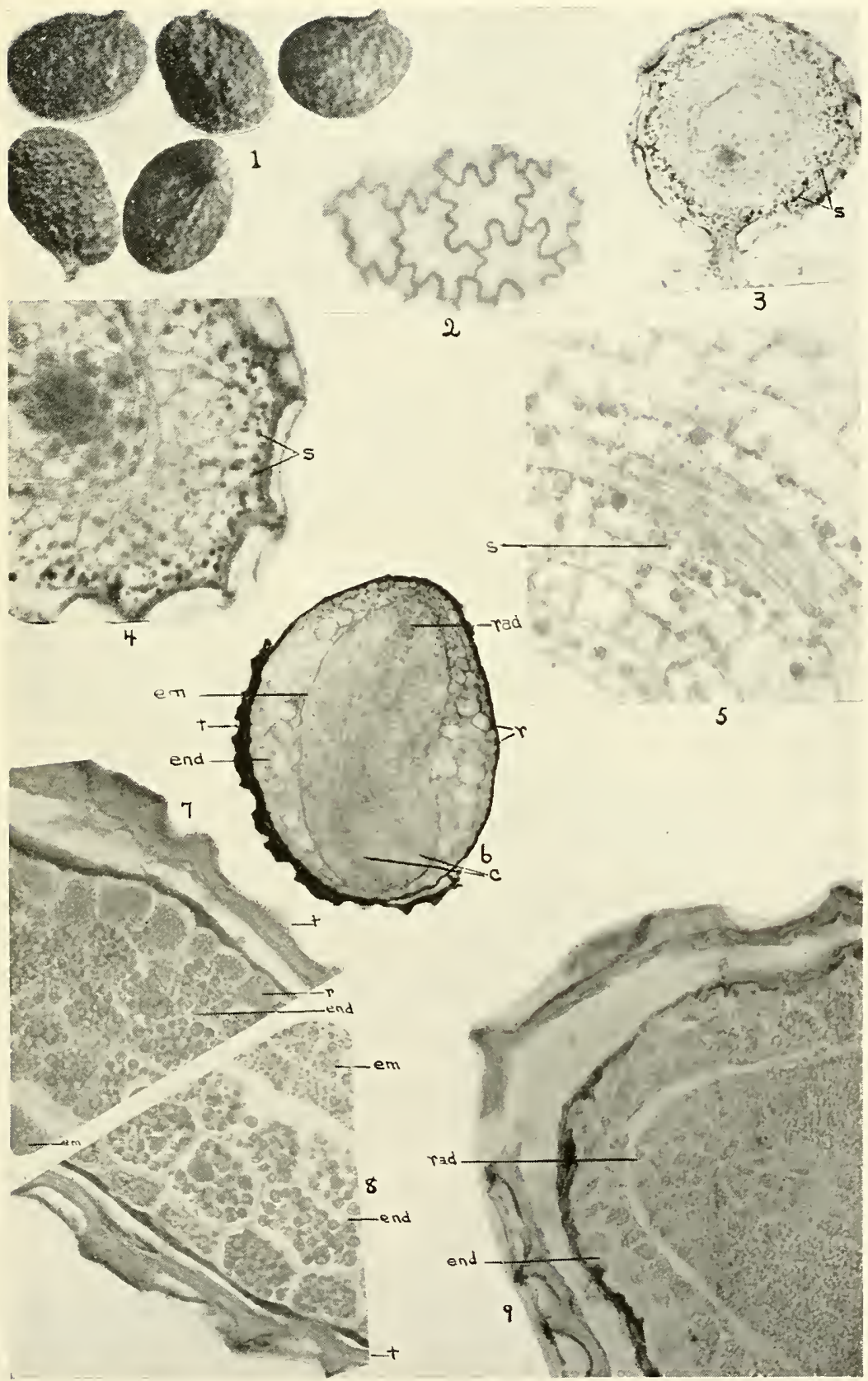



PLATE 19

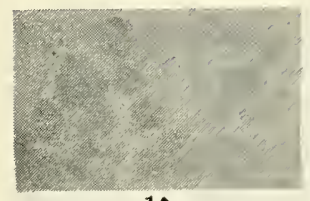

10
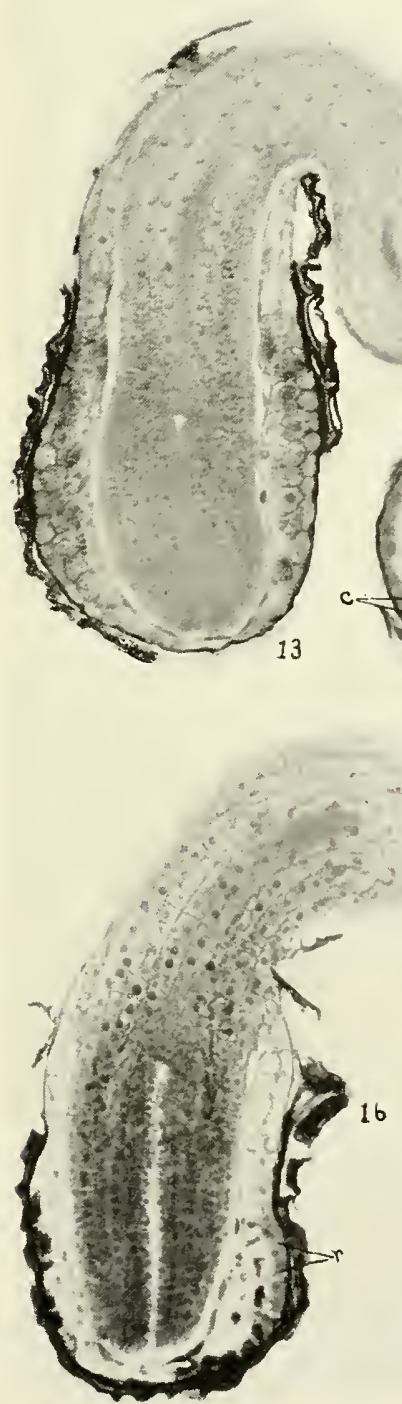

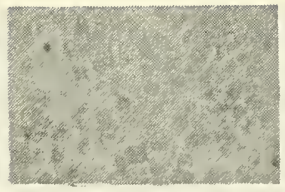

11
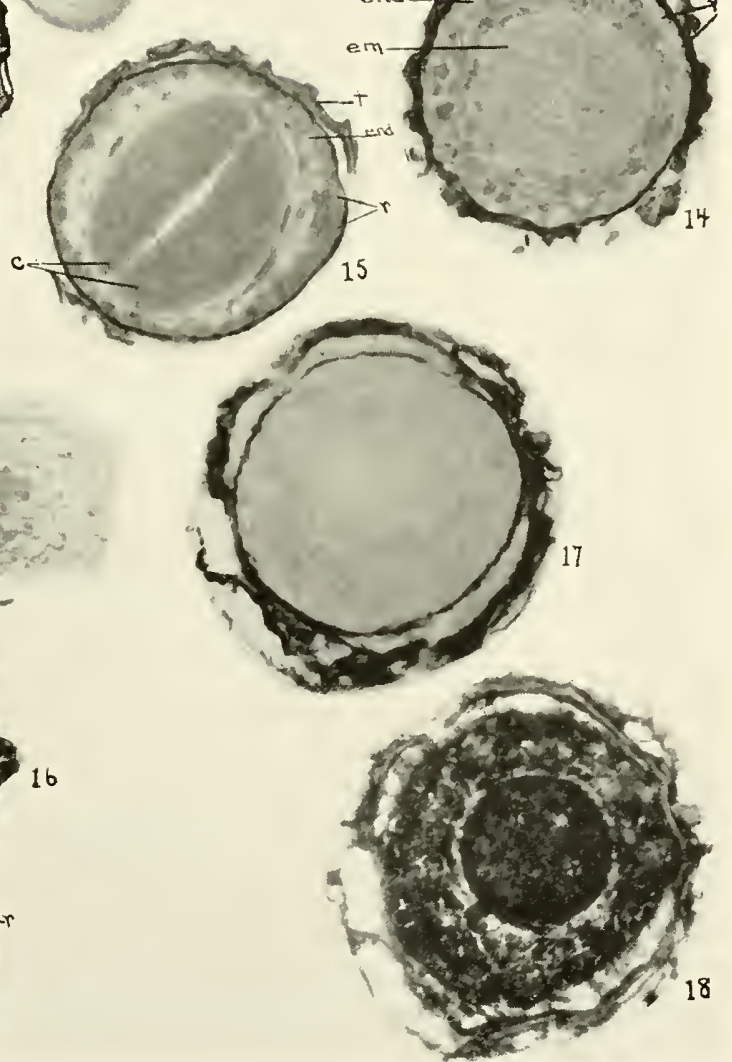



\section{EXPLANATION OF PLATES}

\section{PLATE 18}

FiguRE 1. Mature seeds of Nicotiana Tabacum; $x 30$.

Figure 2. Surface view of testa of seed showing the wary lateral walls; $\mathrm{x} 62$.

Figure 3. Section of ovule of tobacco showing s, starch; $x 62$.

FIGURE 4. Part of section of ovule showing s, starch; $x 165$.

Figure 5. Part of hypocotyl showing s, starch; $x 165$.

FIGURE 6. Section of seed embedded in paraffin but not killed: t, testa; $r$, raphe; end, endosperm; em, embryo ; rad, radicle ; c, cotyledons; $x 62$.

FIGURE 7. Part of section of seed: t. testa; r, raphe; end, endosperm; em, embryo; x 165.

Figure 8. Part of seed opposite that of Fig. 7: t, testa; end, endosperm; em, embryo; x 165.

FIGURE 9. Part of section of seed: rad, radicle; end, endosperm; $x 165$.

\section{PLATE 19}

Figure 10. Protein granules from endosperm; $x 500$.

Figure 11. Protein granules from embryo; $x 500$.

FIGURE, 12. Section of seedling showing the partial disintegration of protein in the endosperm at the radicle end; $x 165$.

FXGURE 13. Section of slightly older seedling showing increased disintegration of protein ; $\mathrm{x} 165$.

Frgure 14. Cross section of seed embedded in paraffin but not killed showing the difference in staining reaction of end, endosperm: r, raphe: em, embryo; $x$ 165. This section was stained with gentian violet alone and shows a typical difference resulting from microchemical tests.

Figure 15. Cross section of seedling slightly older than that of Fig. 13; t, testa ; end, endosperm; r, raphe; c, cotyledons; $x 165$.

FIGURE 16. Section of still older seedling: x 165. Most of the protein of the endosperm is gone but that in the raphe, $r$, is still apparent. At this stage starch is apparent in the hypocotyl as shown in Fig. 5.

FIGURE 17. Cross section of seed embedded in paraffin but not killed. This photograph was made of an unstained section and without the remoral of paraffin; $x 165$.

Figure 18. Same section as that of Fig. 17 after the addition of osmic acid, thus showing fat present both in endosperm and embryo; $\mathrm{x} 165$. 

